\title{
Similibus simile cognoscitur. O pensamento analógico medieval
}

Hilário Franco Júnior

\section{OpenEdition}

\section{Journals}

\section{Edição electrónica}

URL: http://journals.openedition.org/medievalista/344

DOI: 10.4000/medievalista.344

ISSN: 1646-740X

\section{Editora}

Instituto de Estudos Medievais - FCSH-UNL

\section{Refêrencia eletrónica}

Hilário Franco Júnior, « Similibus simile cognoscitur. O pensamento analógico medieval », Medievalista [Online], 14 | 2013, posto online no dia 01 julho 2013, consultado no dia 19 abril 2019. URL : http:// journals.openedition.org/medievalista/344 ; DOI : 10.4000/medievalista.344

\section{(C) IEM}


Título: Similibus simile cognoscitur. $O$ pensamento analógico medieval

Autor(es): Hilário Franco Júnior

Enquadramento Institucional: Universidade de São Paulo, São Paulo, Brasil

Contacto: hilario.franco-jr@wanadoo.fr

Fonte: Medievalista [Em linha]. №14, (Julho - Dezembro 2013). Dir. José Mattoso.

Lisboa: IEM.

Disponível em: http://www2.fcsh.unl.pt/iem/medievalista/

ISSN: 1646-740X

\section{Resumo}

Embora insuficientemente considerado pela historiografia, o pensamento analógico foi o instrumento intelectual predominante em todas as categorias sócioculturais na Europa medieval. Ele é que determinou muitas das formas de relação entre os humanos e destes com a natureza. Levar em conta esta modalidade de raciocínio fundada em homologias, simetrias, contiguidades, correspondências e oposições permite compreender diversas facetas dos conhecimentos, comportamentos e sentimentos do homem medieval. Isto é exemplificado no presente artigo pela frequente utilização que a Idade Média fazia de analogias na matemática, cartografia, medicina, teologia, exegese bíblica, liturgia, etimologia e literatura, dentre outros campos da atividade humana.

Palavras-chave: analogia; pensamento reticulado; saber; agir; sentir. 


\section{Abstract}

Although insufficiently considered by historiography, the analogical thought was the prevalent intellectual instrument in all sociocultural categories in medieval Europe. It was decisive for many forms of relation between the human ones and of those with nature. Taking into account this kind of reasoning based on homologies, symmetries, contiguities, correspondences and oppositions it is possible understand various aspects of knowledge, behaviors and emotions of medieval man. This is exemplified in the present article by the frequent use that the Middle Age made of analogies in mathematics, cartography, medicine, theology, biblical exegesis, liturgy, etymology, and literature, among other fields of human activity.

Keywords: analogy; crosslinked thought; knowledge; activity; feeling.

\section{Similibus simile cognoscitur. 0 pensamento analógico medieval}

\section{Hilário Franco Júnior}

Há alguns anos tentamos mostrar que a ferramenta intelectual predominantemente utilizada no cotidiano da sociedade medieval, qualquer que fosse a instrução formal do indivíduo, foi o pensamento analógico. Isto não significa, é claro, endossar a velha tese de que na longa história do pensamento humano teria havido uma etapa "pré-lógica", o que o próprio Lucien Lévy-Brul nega no fim da vida depois de tê-la anteriormente proposto. Entretanto, tampouco nos parece pertinente falar em "pensamento selvagem" e "pensamento domesticado", como faz Claude Lévi-Strauss, pois embora ele aceite a coexistência das duas modalidades, tais rótulos de grande atração literária deformam o 
conteúdo do que pretendem esclarecer. "Selvagem" não é pensamento violento ou desordenado, tampouco "domesticado" é pensamento submisso. Preferimos por isso ressaltar o modo de funcionamento do aparelho psíquico humano falando em pensamento analógico e pensamento lógico. ${ }^{1}$

Ao se propor a refletir sobre o pensamento selvagem outro grande antropólogo incorre em estranha deformação de perspectiva: "a ilusão é filha da analogia" já que por meio desta um elemento objetivo presente na experiência humana é transmutada em "representação ilusória, portanto subjetiva, do real", ou seja, na qual se "representa as forças e as realidades invisíveis da natureza como seres análogos aos homens", diz Maurice Godelier. Mas tais experiências são objetivas e subjetivas para quem? Não é ao rotulá-las que o observador constrói uma representação subjetiva da realidade observada ao compará-la com a sua própria, que lhe parece a única objetiva? A rigor, contudo, ele implicitamente reconhece, não existe tal objetividade porque "o pensamento selvagem está presente hoje em dia no coração da história e continua o mesmo que ele era no começo da história". E cita Lévi-Strauss: "mesmo a pura reflexão se resume a uma interiorização do cosmos". Ademais, Godelier percebe que o pensamento selvagem "opera em todas as épocas e sobre todos os materiais que lhe fornece a história".2

E não somente o pensamento analógico: tanto ele como o pensamento lógico são de todas as épocas. Ambos são atestados pelo menos desde o começo do Paleolítico superior, há 40 mil anos, quando a representação gráfica mostra que o espírito humano já estabelecia relações analógicas, por exemplo, entre o bisonte pintado no fundo de uma caverna e o animal que se conhecia e caçava, ou entre uma pequena estatueta de mulher de formas generosas (as "Vénus esteatopígias" dos paleo-arqueólogos) e as fêmeas humanas cuja fecundidade provocava respeito e admiração. Todas estas figuras são estereotipadas, não remetem a indivíduos concretos e particulares (um bisonte, uma

${ }^{1}$ FRANCO JÚNIOR, Hilário - "Modelo e Imagem: o pensamento analógico medieval". Bulletin du Centre d'Etudes Médiévales. Hors Série 2 (2008). http://cem.revues.org/index9152.html (online desde 28/2/2009), reproduzido em IDEM - Os três dedos de Adão, p.93-128; LÉVY-BRUHL - La mentalité primitive. Paris : Alcan, 1922; IDEM - Les carnets de Lucien Lévy-Bruhl. Ed. Maurice Leenhardt. Paris: PUF, 1949; LÉVI-STRAUSS - La pensée sauvage. Paris: Plon, 1962.

2 GODELIER - "Mythe et histoire: refléxions sur les fondements de la pensée sauvage". Annales. Économies. Sociétés. Civilisations. Paris. 26 (1971), p.544-545, 552, 555. A citação de Lévi-Strauss é extraída de La pensée sauvage, p. 328. 
mulher) e sim a gêneros (o bisonte, a mulher) e ideias gerais (a caça, a reprodução), traço típico do pensamento analógico. Ao mesmo tempo, tais representações revelam "evidências geométricas incontestáveis" como a consciência e a utilização da bidimensionalidade e da tridimensionalidade, a comparação de grandezas, o senso de proporcionalidade. Ou seja, tais figurações são materializadas por meio do pensamento lógico. No trabalho paleolítico, conclui Olivier Keller, "é o pensamento, a reflexão, que guia a mão", os resultados decorrem do "pensamento geométrico implícito, e não de uma simples habilidade manual". ${ }^{3}$

As duas modalidades de pensamento convivem, portanto, todavia não deixam de apresentar predominâncias diferentes conforme as idades do homem ${ }^{4}$ e as épocas da história. No Ocidente, o olhar lógico sobre o mundo demoraria a se impor, apesar dos inegáveis progressos conhecidos a partir do século XII e analisados por Alexander Murray. ${ }^{5}$ Mas, filha de seu tempo, a erudição dos séculos XIX-XX, fundada na abstração, resistiu a reconhecer o papel central desempenhado pelo pensamento analógico pelo menos até o século XVII. É o que ilustra a dupla explicação histórica da descoberta da gravitação universal. A versão erudita reporta-se ao trabalho de Newton sobre as equações de Kepler, enquanto a versão popular fala na queda de uma maçã sobre a cabeça do cientista - ou seja, a primeira exegese daquela descoberta científica é cumulativa, lógica, a segunda intuitiva, analógica. A maçã caiu por ter sido atraída, da mesma forma que todo corpo material cai em direção à Terra, observação e conclusão derivadas do interesse de Newton pela alquimia, cuja hipótese básica é analógica, a de que a matéria se atrai e repulsa mesmo à distância.

O caso do estudo justamente célebre de Erich Auerbach sobre o conceito de figura, central para a Europa cristã medieval, também é bastante ilustrativo. Nas palavras daquele autor, "a interpretação figural estabelece entre dois acontecimentos ou duas pessoas uma conexão na qual um deles não atribui significado tanto a si mesmo quanto ao outro, enquanto este abrange ou preenche o primeiro." Ele reconhece, assim, que ao colocar uma coisa no lugar de outra a interpretação figural "faz parte das formas

\footnotetext{
${ }^{3}$ KELLER - Aux origines de la géométrie. Le paléolithique et le monde des chasseurs-cueilleurs. Paris : Vuibert, 2004, p. 119.

${ }^{4}$ Jung mostrou que certos estágios da vida psíquica funcionam no modo analógico: JUNG, Carl G. - A dinâmica do inconsciente. Petrópolis: Vozes, 1984 (Obras completas, VIII).

${ }^{5}$ MURRAY - Reason and society in the Middle Ages. Oxford: OUP, 1978.
} 
alegóricas na sua acepção mais larga", e percebe que "o analogismo [...] da Idade Média está estreitamente ligado à estrutura figural”, porém restringe seu alcance naquela época aos "campos da atividade espiritual". Mais discutível ainda é a afirmativa do grande erudito alemão de que uma civilização precisa estar na sua fase descendente "para poder produzir um fenômeno como a interpretação figural", 6 o que significa propor uma inaceitável lei histórica e desconsiderar o caráter transhistórico da abordagem analógica da realidade material e espiritual.

Contudo, desde meados do século XX passou-se a reconhecer a grande eficácia epistemológica do pensamento analógico. Nas Ciências Exatas, para pensar a natureza ondulatória da luz o fisico James Maxwell estabelece uma analogia com a natureza ondulatória do som, que se difunde no ar, e que por sua vez tinha sido imaginada a partir de analogia com as ondas que se propagam na água de um lago quando ali se joga uma pedra. Nas Ciências Cognitivas, propõe Max Turner, é a imaginação criativa, baseada no recurso espontâneo à analogia, que permite captar a estrutura oculta entre duas coisas ou situações aparentemente afastadas e assim construir o conhecimento. Nas Ciências Sociais, Fernand Braudel defende que a pesquisa das similitudes é a "verdadeira condição de toda ciência social", o que seria posteriormente aceito por vários estudiosos. ${ }^{7}$

Enfim, como demonstra Michel Foucault, o saber não se constituiu ao termo de um processo racional, e sim de uma arqueologia por meio da qual os sistemas de invariância típicos do conhecimento científico fundam-se sobre semelhanças: o pensamento analógico desempenhou "um papel construtor no saber da cultura ocidental" até fins do século XVI, diz ele ${ }^{8}$ até meados, talvez fins, do século XVII, pensamos nós.

\footnotetext{
6 AUERBACH - "Figura" [1938], em IDEM - Studi su Dante. Milão: Feltrinelli, 1981, p. 174-235 (citações procedentes das p. 204, 205, 208, 211).

${ }^{7}$ MAXWELL - A treatise on electricity and magnetism. Oxford: Clarendon, 1873; TURNER - The artful mind: Cognitive science and the riddle of human creativity. Oxford: OUP, 2006; BRAUDEL - L'identité de la France. Espace et histoire. Paris: Arthaud-Flammarion, 1986, p.15; VVAA - Métaphores et analogies, schèmes argumentatifs des sciences sociales, número temático da Revue européenne des sciences sociales. Genebra. 38, 117 (2000).

${ }^{8}$ FOUCAULT - As palavras e as coisas, p.73.
} 
Limitando-nos àquilo que agora interessa, o raciocínio analógico prevaleceu na Europa cristã medieval sem com isso dispensar procedimentos lógicos. A título de ilustração, se o gênero literário do exemplum para bem cumprir sua função moralizante fundava-se em analogias entre fatos e personagens profanos e fatos e personagens sagrados, as coletâneas de exempla a partir de meados do século XIII introduzem elementos de organização lógica para facilitar sua utilização pelos pregadores: numeração dos relatos, agrupamento deles por assuntos classificados em ordem alfabética, índice pelos títulos dos exempla, a partir de 1300 índices remissivos (alphabetum narrationum). O cristianismo, aliás, não é refratário ao pensamento lógico, pelo contrário, já que aceita um ponto de partida ou causa primeira, Deus, da qual decorrem as outras. Mais do que isto, assinala Alexandre Kojève, a ciência moderna é produto do cristianismo cujo dogma da Encarnação possibilita projetar a Terra no Céu e assim estabelecer uma identidade científica essencial entre eles. ${ }^{9}$

O entendimento lógico das coisas sagradas é contudo limitado, levando Ricardo de Saint-Victor (c.1123-1173) a justificar o mecanismo intelectual analógico: "por causa de nossa fraqueza (infirmitati), que não pode compreender o alto pelo baixo, o espiritual pelo corporal, é necessário não tentar compreender o desconhecido pelo desconhecido, e sim pelo que é conhecido". Foi o que fez em meados do século XIII o arcebispo de Gênova ao tentar explicar o abstrato e complexo conceito da Trindade: as três pessoas divinas têm uma só essência assim como a videira é composta de madeira, folhas e fruto. Em um sermão de meados de 1495, o dominicano Savonarola afirmou que se as razões de Deus são impenetráveis é por estarem fundadas em visão sincrônica do universo. ${ }^{10}$ Como resume um estudioso moderno, Robert Javelet, por toda Idade Média "não existe verdadeiro conhecimento se não existe semelhança entre o sujeito e o

9 KOJÈVE - “L’origine chrétienne de la science moderne”. Em Mélanges Alexandre Koyré. Paris : Hermann, 1964, vol.II, p.295-306.

${ }^{10}$ RICARDO DE SAINT-VICTOR - In Apocalypsin Joannis, I,1. Em Patrologia Latina, vol. 196, col.688a; JACOPO DE VARAZZE - Legenda áurea, cap.5,§3, p. 85; SAVONAROLA - Prediche sopra i Salmi, 25. Ed. Vincenzo Romano. Roma : Angelo Belardetti, 1974 (Edizione Nazionale delle Opere di Girolamo Savonarola), vol.II, p.127-151. 
objeto", o que se estende ao século XVI de que fala Foucault: "procurar o sentido é trazer à luz o que se assemelha". ${ }^{11}$

Já se chamou atenção, com razão, que se ricas civilizações como a chinesa antiga e a muçulmana medieval não realizaram uma revolução científica semelhante à ocidental do século XVII, é porque não contaram com a forma de raciocínio proposta pela escolástica cristã. De fato, mais do que um sistema de ideias esta foi um método de investigação que procurava harmonizar o contraditório, basicamente a lógica aristotélica e a revelação cristã. Procedimento possível não apenas pela redescoberta em meados do século XIII das obras completas de Aristóteles, mas sobretudo porque tal postura estava contida na própria religião: "sou devedor a gregos e a bárbaros, a sábios e a ignorantes", tinha afirmado São Paulo. Mais importante, "as perfeições invisíveis de Deus tornaramse visíveis desde a criação do mundo". Ou seja, porque o Logos se encarnou a divindade manifesta-se pela sua Palavra e pela sua Obra, diferentemente do judaísmo e do islamismo que ao valorizarem apenas a Palavra - "o Corão ocupa no islamismo quase a mesma posição que a pessoa de Cristo ocupa no cristianismo", avalia Francis Oakley não procuram Deus no livro inteligível da natureza. ${ }^{12}$

Bem entendido, a plenitude das conseqüências desta postura teológico-filosófica (que não foi, claro, linear e unânime) seria alcançada apenas mais tarde e ainda assim sem isentar o cristianismo de relações analógicas que não lhe são secundárias, e sim constitutivas. A relação entre Deus e tudo é de causalidade, afirma Tomás de Aquino, mas como Ele não gera iguais a si (como faz o homem, causa unívoca) é agens analogicum, é causa análoga do mundo. Daí porque "é conveniente que na Santa Escritura as coisas espirituais nos sejam comunicadas por meio de metáforas corporais", ou seja, toda Revelação se dá por analogia. ${ }^{13}$ Assim, quando Guilherme de Auvergne

11 JAVELET - "Psychologie des auteurs spirituels du XIIème siècle". Revue des sciences religieuses. Estrasburgo. 33 (1959), p.215; FOUCAULT - As palavras e as coisas, p.85.

12 Romanos I,14.20; OAKLEY - The medieval experience. Foundations of Western cultural singularity [1974]. Toronto: University of Toronto Press / Medieval Academy of America, 1988, p.154. Mesmo no interior do islamismo atual alguns concordam com esta análise, caso do filósofo Hamadi Redissi, professor da Universidade de Tunis, para quem "todos os pré-requisitos para uma autêntica abordagem científica são inencontráveis no Corão": Philosophie Magazine. Paris. 65 (dez. 2012-jan. 2013), p.32.

${ }^{13}$ Summae Theologiae. Ed. Leonina. Roma: Polyglotta, 1888 (Opera omnia, 4), I-I, q.13, a.5, p.147 (sicut in praedicationibus omnia univoca reducuntur ad unum primum, non univocum, sed analogicum); I-I, q.1, a.9, p.24 (unde convenienter in sacra Scriptura traduntur nobis spiritualia sub metaphoris 
(c.1185-1249) critica os filósofos que identificam as nove ordens angelicais às nove inteligências do sistema cosmológico de Aristóteles, ${ }^{14}$ ele não contesta o procedimento analógico em si, mas, pelo contrário, a pretensão daqueles pensadores em restringirem a questão a um plano puramente lógico recorrendo ao Estagirita.

É por "imagem e semelhança", portanto analogicamente, que se definem o Criador e a criatura, embora a percepção que se tem deles no mundo terreno seja assimétrica: "agora vemos obscuramente através de um espelho, depois veremos face a face" explica o texto paulino. ${ }^{15}$ Porque a criatura está contida no Criador e este não está ausente daquela, havia todo um jogo especular entre microcosmo e macrocosmo.

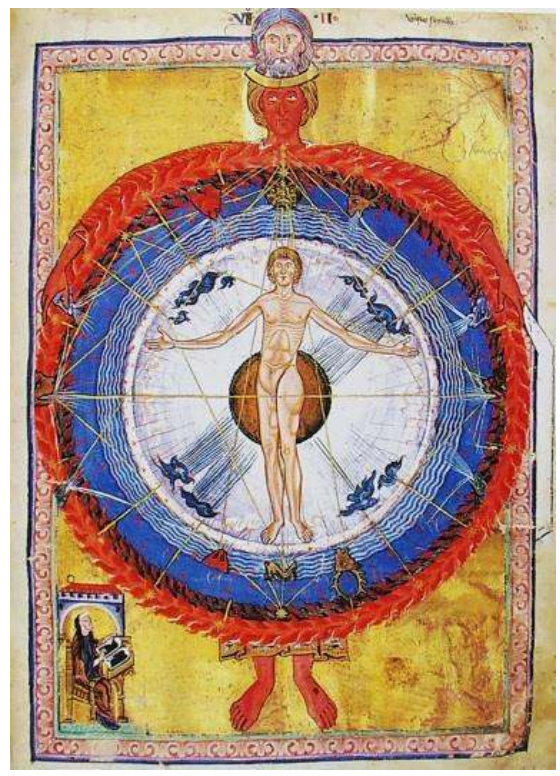

Fig. 1 O homem microcósmico ${ }^{16}$

corporalium). "A partir do momento em que se interpreta a causalidade como um dom do ser, está-se necessariamente levado a estabelecer uma nova relação entre o efeito e sua causa, a da analogia", pondera GILSON - L'esprit de la philosophie médiévale, p.96.

${ }^{14}$ De Universo, II,2,112. Em Opera omnia. Frankfurt: Minerva, 1963, vol.I, p.964e.

15 "Faciamus hominem ad imaginem et similitudinem nostram" (Gênese I,26); "Videmus nunc per speculum in aenigmate, tunc autem facie ad faciem" (1 coríntios XIII,12).

${ }^{16}$ Iluminura presente em HILDEGARDA DE BINGEN - Liber divinorum operum. Lucca: Biblioteca Statale, ms. 1942, fol.9, aqui reproduzida da edição do Corpus Christianorum Continuatio Medievalis (= CCCM), prancha 7. 
Não é casual, pois, que na Europa medieval até os séculos X-XI o cristianismo oficial não tenha conseguido encobrir o paganismo e sua profunda relação analógica com o mundo. Se a partir do século XII (e depois, em novo patamar, do XVII) o pensamento lógico ganhou força, não poderia, pelas razões explicadas, excluir o analógico. Por exemplo, as catedrais góticas atestam na sua construção um bom domínio da lógica geométrica e ao mesmo tempo apresentam uma decoração escultórica, pictórica e de vitral plena de relações analógicas. Ou seja, aquilo que a erudição moderna chama de simbolismo, entendido como leitura mística do universo, nada mais é que um procedimento analógico. Se $\sigma 0 ́ \mu \beta$ o ao serem reagrupadas permitem a identificação de uma pessoa ou um objeto, este reagrupamento ocorre por semelhança do material, por complementaridade da forma, por reconhecimento do significado.

Para lembrar um único caso, é o que acontece com a difundida imagem dos Tetramorfos. São João diz no Apocalipse ter visto à volta do trono do Todo-Poderoso quatro criaturas aladas, um homem, um touro, um leão e uma águia, ${ }^{17}$ o que os primeiros pensadores cristãos submeteram a uma exegese seguida desde então. Santo Ireneu por analogia numérica viu neles os quatro evangelistas. São Jerônimo por analogia formal especificou que o homem é imagem de Mateus cujo Evangelho começa com a genealogia do Encarnado, o touro é Lucas que inicia seu relato pelo sacrificador Zacarias, o leão é Marcos que à partida fala em João Batista, o leão do deserto, a águia é João que logo à entrada de seu texto se eleva em direção das verdades eternas. Gregório Magno por analogia de sentido estabeleceu correspondências entre cada uma daquelas criaturas e os atributos de Cristo, que é homem no seu nascimento, touro na sua morte, leão na sua ressurreição (de acordo com os bestiários, animal natimorto e ressuscitado pelo sopro do pai sobre ele $)^{18}$ e águia na sua ascensão.

Portanto, pensamento analógico é aquele centrado mais nas relações entre as coisas que nas coisas em si mesmas. É mais sintático que semântico. Isto implica dizer que o mundo é constituído de elementos heterogêneos que fazem parte de um todo coerente, uma rede de homologias, simetrias, contiguidades, correspondências, comparações,

\footnotetext{
${ }^{17}$ Apocalipse IV-7-8.

${ }^{18}$ Physiologus latinus. Versio B, I,14-17. Ed. Francis J. Carmody. Paris : Droz, 1939, p.10-11.
} 
oposições. Embora cada elemento esteja investido de significado próprio, apenas no interior da rede ele ganha todo seu sentido e exerce todas suas possibilidades funcionais. Devido a este fundamento o pensamento analógico é indutivo, ou seja, conforme a clássica definição de Cícero, é raciocínio que extrai as conclusões de elementos exteriores à coisa examinada enquanto o raciocínio dedutivo o faz a partir da própria coisa observada. ${ }^{19}$

As relações analógicas eram favorecidas pela cultura oral da maior parte da população medieval. Com efeito, todo idioma funciona de maneira essencialmente analógica, sua aprendizagem se dá por emulação. A formação do vocabulário, aquilo que a linguística moderna chama de "arbitrário do signo", ocorre por meio de processo analógico, como demonstra em qualquer língua a simples consulta aos dicionários ditos, justamente, analógicos. A linguagem gestual dos monges também recorria a analogias - se exprimir um ato concreto não era difícil (para "calar", colocava-se o indicador sobre os lábios fechados, como fazemos ainda hoje), abstrações pediam procedimentos analógicos: o conceito de "pobreza" era indicado pela fricção das unhas dos polegares, como que a esmagar uma pulga ou piolho, ${ }^{20}$ isto é, por meio da descrição gestual de uma má condição de higiene derivava-se para a idéia de carência, de pobreza.

O caráter fortemente analógico das línguas era reforçado pelo agrafismo, pois ler e escrever implica também um mecanismo lógico, linear, de organização das letras e linhas (seja da direita para a esquerda como no hebraico e no árabe, ou o inverso no grego, no latim e nas suas derivações) e do conjunto textual com pontuação, paragrafação e índices (instrumentos intelectuais desenvolvidos a partir do século XII). É essa superioridade da escrita e do pensamento lógico que transparece com força na bela fórmula de Pedro Lombardo, em meados do século XII: "nam cum oramus, cum Deus ipsi loquimur; cum vero legimus, Deus nobiscum loquitur" (quando oramos falamos com Deus, quando lemos é Deus que fala conosco). ${ }^{21}$

Mas tanto na fala quanto na escrita estão sempre presentes as figuras de linguagem, procedimentos analógicos (ainda que de tipos diversos) de uso tão frequente no

\footnotetext{
${ }^{19}$ CICERO - De l'invention, I,31-34, p.102-107.

${ }^{20}$ Como o silençio seia chave da Religião. Lisboa: Biblioteca Nacional de Portugal, Cod. Alc. CCCL/91, fol. 20v. Embora este códex seja de 1547, expõe práticas bem anteriores no mundo monástico.

${ }^{21}$ Sententiae, III,VIII,2. Quaracchi: Colegii S. Bonaventurae, 1971, p.429.
} 
cotidiano que geralmente não nos damos conta delas, sobretudo a metáfora, a metonímia e a sinédoque. A primeira é analogia de propensão que estabelece laços entre termos de domínios diferentes (transposição do significado de uma palavra a outra), a segunda é analogia de atribuição extrínseca que constrói elos no interior de um mesmo domínio (causa pelo efeito, efeito pela causa, continente pelo conteúdo), a terceira é analogia de atribuição intrínseca (o todo pela parte, a parte pelo todo, a espécie pelo gênero, o gênero pela espécie, etc.). Mais do que isso, desde a análise aristotélica sabe-se que a metáfora é instrumento de conhecimento. Consciente disso, um professor de retórica da importante Universidade de Bolonha afirmou em 1235 que a metáfora (transumptio) “sem dúvida foi inventada no Paraíso terreno", e pelo próprio Deus (ipse plasmator). ${ }^{22}$

Nas sociedades arcaicas, inclusive a da Europa cristã medieval, o pensamento analógico além de instrumento cognitivo exerce importante função psicológica acalmando a angústia diante de um mundo percebido como extremamente fragmentado e ao qual dá certa ordenação. Humanos de variadas aparências e costumes, animais e plantas de características bem diversas, terras de clima, solo, fauna e flora muito distintos, mundo sobrenatural forçosamente misterioso e com frequência assustador, tudo ganha inteligibilidade por meio do pensamento analógico, "um dos instrumentos mais versáteis da cognição humana". ${ }^{23}$ Daí porque no Ocidente medieval ele esteve presente em todos os níveis sócioculturais, sendo aplicado a campos de reflexão que nos parecem hoje estritamente lógicos, dedutivos.

${ }^{22}$ ARISTÓTELES, 1410b - Rhétorique. Ed.-trad. Médéric Dufour e André Wartelle. Paris : Les Belles Lettres, 1989, p.63; BONCOMPAGNO DA SIGNA - Rhetorica novissima, IX,2, p.281. É interessante verificar que para estudiosos modernos a metáfora em certa medida define o homem. O sentido próprio das palavras seria vestígio de metáforas perdidas, "mortas", enquanto o sentido figurado seriam metáforas “vivas”, sugere RICOEUR, Paul - La métaphore vive. Paris: Seuil, 1975. Todas as idéias são metáforas porque o homem não busca nomear as coisas, e sim suas experiências diante de cada situação, avaliam LAKOFF, George e JOHNSON, Mark - Metaphors we live by. Chicago: University of Chicago Press, 1980. A metáfora não é mero dado lingüístico, e sim semiótico, está presente em quase todos os sistemas de signos, estima ECO - "Metáfora", p.201. Até mesmo um matemático admite que "todo conhecimento é metafórico": THOM, René - Apologie du logos. Paris: Hachette, 1990, p.641.

${ }^{23}$ DESCOLA, Philippe - "Un monde enchevêtré". Em IDEM (dir.) - La fabrique des images. Visions du monde et formes de la représentation. Paris: Musée du Quai Branly / Somogy, 2010, p.165. 
É o caso da aritmética. Isidoro de Sevilha concebia no começo do século VII a existência do número circular, aquele que multiplicado por outro igual (similiter) "começa e volta para si mesmo" (ase inchoans ad se convertitur), como o ser humano feito da terra e destinado a voltar a ela, segundo o texto bíblico. ${ }^{24}$ Sendo o cinco o primeiro número circular, entende-se que o mundo estivesse dividido em cinco partes (céu, mar, Ásia, Europa e África), o ser humano em cinco sentidos (visão, audição, olfato, paladar, tato), os animais em cinco tipos (quadrúpedes, répteis, vermes, peixes, aves). A abadessa Hildegarda de Bingen confirmaria, em texto de 1163-1173, que o homem é como o globo terrestre, constituído por cinco zonas, nele correspondentes aos cinco sentidos, mesmo porque, ela já dissera em 1141-1151, o homem na origem tinha sido o número dez, perfeito, mas acabou diminuído pelo pecado e recuperado pelas cinco feridas de Cristo. ${ }^{25}$ Acreditando, como muitos pensadores medievais, que definição de fundo analógico - todo número par é feminino e todo ímpar masculino (dos quais se exclui o 1, a unidade criadora, fora da escala propriamente quantitativa dos números), Thibaut de Langres em fins do século XII também identificava o número cinco ao mundo e ao homem, ambos constituídos pelo primeiro par (2) e pelo primeiro ímpar (3), ou seja, pelo feminino e pelo masculino. ${ }^{26}$

É o caso, igualmente, daquilo que a erudição moderna chama de cartografia e que mais exatamente era representação simbólica do mundo. Seu tipo mais difundido a partir do século VIII, herdado das concepções gregas clássica e pré-ptolomaica, é conhecido por OT (orbis terrarum), no qual O é o círculo do mundo habitado em que está inscrito o T cujo braço vertical é o Mediterrâneo que divide a Europa (abaixo e à esquerda) da África (abaixo e à direita) e cujo braço horizontal representa os rios Tanais (hoje Don) e Nilo acima dos quais se localiza a Ásia, que ocupa então a metade superior do círculo (Figura 2):

\footnotetext{
${ }^{24}$ Etimologías, III,7,5, vol.I, p.432; XI,1,4, vol.II, p.12 (cf. Gênese III,19).

${ }^{25}$ Liber divinorum operum, II,V,2-3; Scivias, III,II,20-21. Ed. Adelgundis Führkötter. Turnhout: Brepols, 1978 (CCCM 43A), p.366-367.

${ }^{26}$ Traité sur le symbolisme des nombres. Ed.-trad. René Deleflie. Langres: Dominique Gueriot, 1978, I,C, p.144; II,A, p.146; III,A, p.159.
} 


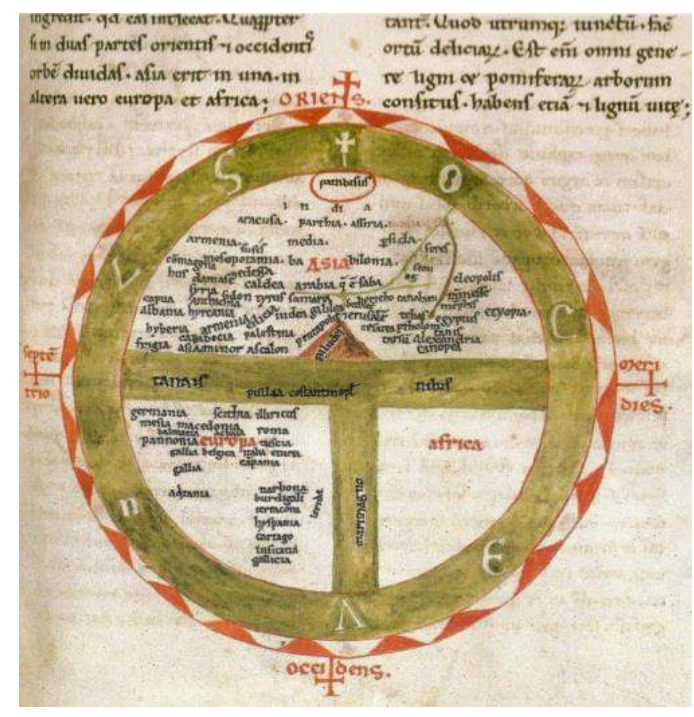

Fig. 2 Mapa-múndi $\mathrm{OT}^{27}$

Ora, mais do que localizar os acidentes geográficos, muito esquematizados, este tipo de "mapa" figura a divindade por meio da perfeição do círculo (o "O”) e nela inscreve a própria divindade humanizada e crucificada (o "T"). Em certos casos, como no célebre mapa de Ebstorf, esta ideia ficava explicitada graças ao desenho das extremidades antropomórficas de Deus, cujo corpo é o próprio círculo (Figura 3). Ademais, a tripartição do ecúmeno estava desde Isidoro de Sevilha associada à divisão da Terra entre os filhos de Noé, cujos nomes estão escritos dentro de cada continente (Sem na Ásia, Cam na África, Jafé na Europa) em um mapa do século VIII incluído num manuscrito daquele texto. ${ }^{28} \mathrm{Ou}$, mais minuciosamente, como acontece em um mapamúndi inglês dos arredores de 1300, cada parte do mundo assinala as províncias povoadas pelos descendentes de Noé. ${ }^{29}$

\footnotetext{
${ }^{27}$ Iluminura confeccionada na França do sul em meados do século XII para uma cópia das Etymologiae de Isidoro de Sevilha - Aix-en-Provence: Biblioteca Municipal, ms. 25, p.293 (reproduzida em DALARUN, Jacques (dir.) - Le Moyen Âge en lumière, p.55).

${ }^{28}$ ISIDORO - Etimologías, XIV,2,1-3, vol.II, p.164-167. O manuscrito citado é Etymologiae, BnF, ms. lat. 7592 , fol.120.

${ }^{29}$ Mapa da abadia de Reading (8,7 x 7,5 cm). Londres: Lambeth Palace Library, ms. 371, fol.9v.
} 


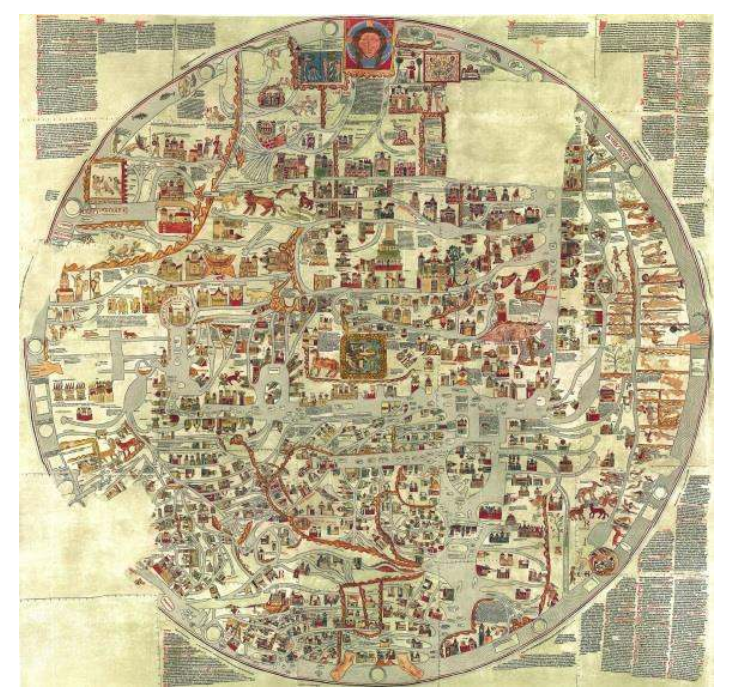

Fig. 3 O mundo como corpo de Deus ${ }^{30}$

Se na história da medicina há duas grandes tendências, uma que busca a cura pelo semelhante, outra pelo contrário, sem dúvida na maior parte do tempo prevaleceu a do similia similibus curantur (base ainda hoje da medicina homeopática), adaptação terapêutica do princípio-base do pensamento analógico - "o semelhante vai com o

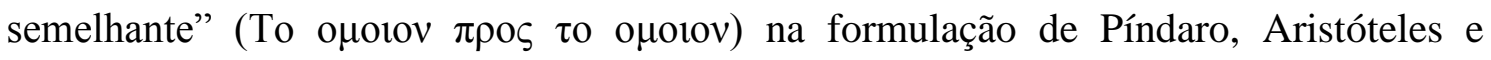
Teofrasto, "somente o semelhante conhece o semelhante" (similibus simile cognoscitur) na de Agostinho. Daí a prática popular de tratar uma criança febril colocando-a três vezes no forno, conforme relata Burchard de Worms no começo do século XI e Les livres du roy Modus et de la royne Ratio no século XIV. ${ }^{31}$ Porque o semelhante pede o semelhante, a ingestão de elemento contrário pode se revelar perigosa: para o cérebro

${ }^{30} \mathrm{O}$ original, de mais ou menos 1300, era composto de 30 peças de pergaminho e media 358 x $356 \mathrm{~cm}$. Ele foi destruído durante bombardeio em 1943, mas tinha sido anteriormente publicado em facsímile por MILLER, Konrad - Mappae mundi, die ältesten Weltkarten. Stuttgart: Joseph Roth, 1896, vol.6. A imagem aqui reproduzida resulta de longa reconstituição terminada em 2006 e consultável em www.landschaftsmuseum.de/.../Ebstorferin_\%20Wissenschaft.htm (acessado em 28/12/2012).

${ }^{31}$ Citados por BOLOGNE - Da chama à fogueira, p.101 e 106. 
humano, sede da alma, faz mal comer cérebro de animais, excepto de cão e raposa, ${ }^{32}$ mais inteligentes que os outros animais.

Explorando as supostas propriedades curativas das pedras, consideradas seres vivos e atuantes, sexuados e reprodutores, tratados de litoterapia foram por muitos séculos ensinados nas faculdades de medicina de Salerno e Montpellier, as mais importantes da época. A eficácia que se lhes atribuía ocorria por simpatia, ou seja, pela relação que existe entre sua forma, sua cor, seu sexo e a afecção que se pretendia curar. Por exemplo, o berilo pela sua cor amarela tratava de icterícia e todas as doenças do fígado, enquanto a cornalina, a sardônia e as pedras vermelhas em geral cuidavam de doenças ligadas ao sangue. ${ }^{33}$

É a mesma noção analógica de medicina que se encontra, para ficarmos com duas obras de tempos e espaços diferentes, no Causae et curae da alemã Hildegarda de Bingen, dos arredores de 1155, e no Liber de conservanda sanitate do português Pedro Hispano, de meados do século XIII. Para a abadessa, seguindo longa tradição, os elementos dos quais Adão foi formado (do fogo procede seu calor, do ar sua respiração, da água seu sangue, da terra sua carne) transformaram-se, por causa do Pecado Original, em fleumas prejudiciais. ${ }^{34}$ Se estes não conseguem subir até ao cérebro do homem que tem bons pensamentos, eles podem ficar na garganta e daí se espalhar pelos pulmões, provocando doenças nestes órgãos. Ou então, se o homem foi concebido no signo de Câncer, quando o sol está no seu apogeu, terá o fígado são, o que encaminha os mali humores para o coração. ${ }^{35}$ Esta concepção das doenças determinava a dos remédios, como mostram as fórmulas e os tratamentos que Hildegarda propõe.

De seu lado, o teólogo e professor de medicina na Universidade de Siena (1246-1252), depois pontífice sob o nome de João XXI (1276-1277), recolheu centenas de receitas de

\footnotetext{
${ }^{32}$ Liber de conservanda sanitate, em Obras médicas de Pedro Hispano, p.454-457.

${ }^{33}$ MARBODE - Poème des pierres précieuses, 12. Ed. John M. Riddle, trad. Pierre Monat. Grenoble : Jérôme Millon, 1996, p.31; HILDEGARDA DE BINGEN - Le livre des subtilités des créatures divines (Physique). Ed. Charles Daremberg, trad. Pierre Monat. Grenoble : Jérôme Millon, 1996, vol.I, 7, p.217, 23, p.238; ALBERTO MAGNO - Le monde minéral. Les pierres. Ed. Auguste Borgnet, trad. Michel Angel. Paris: Cerf, 1995, p.229 e 242.

${ }^{34}$ Causae et curae, II, p.49, linhas 35-37 (cf. também p. 43, linhas 13-14); p.50, linhas 16-18 (cf. também p.36, linhas 13-15).

${ }^{35}$ Ibidem, II, p.96-97; p.98, linhas 21-28.
} 
remédios, próprias e de outros, essencialmente fundadas em analogias. Algumas vezes estas decorriam, ao menos em parte, da forma do órgão doente. Contra doenças de ouvido ele prescreve: "ponha-se numa cebola oca azeite e suco de alhos porros, losna [absinto] e leite de mulher; coza-se nas brasas, esprema-se e ponha-se uma gota no ouvido [...]. É uma receita excelente." ${ }^{36}$ Para resolver a esterilidade, a mulher deve comer uma vulva de lebre. ${ }^{37}$ Outras vezes a cura pretendida se dá por contágio: contra dor de dente é preciso tocar o dente doente com um dente de homem morto (portanto indolor); para expelir um cálculo renal, deve-se em jejum engolir um cálculo humano que quebra o já existente e arrasta-o para fora ${ }^{38} \mathrm{O}$ efeito desejado também pode ocorrer pela função análoga do remédio: como afrodisíaco, comer testículos de raposo; como anticoncepcional, untar-se com sangue menstrual de outra mulher. ${ }^{39}$

O direito medieval, por sua vez, tanto o costumeiro como o canônico, aceitou por muito tempo uma prática de fundamento analógico, o ordálio. O pressuposto era que atitudes recrimináveis de um só indivíduo podem afetar a ordem universal e prejudicar assim todo o grupo social, sendo então preciso descobri-las e puni-las para acalmar a cólera divina, já que para as sociedades arcaicas "causas iguais produzem fenômenos jurídicos e sociais iguais". ${ }^{40}$ De fato, o ordálio era justificado pela lei da similitude, segundo a qual o mal atrai o mal e revela o culpado, ou bem e mal se repelem e indicam o inocente. Embora certos pensadores tenham condenado tal prática - mas apenas por razões religiosas, acreditando que ela atentava contra a imperscrutabilidade da justiça divina - caso de Gregório Magno, Rábano Mauro e Agobardo de Lyon, no século VIII ela foi introduzida no direito eclesiástico e tornou-se de uso quase geral até fins do século XI. A própria Igreja recorria a ela em certos casos, sobretudo quando de suspeição de heresia, e em meados do século XII a grande suma de Graciano acabou por incorporar o ordálio. Este procedimento judiciário recuaria no século XIII quando, decorrência do avanço do pensamento lógico, a Igreja proibiu que os clérigos

\footnotetext{
${ }^{36}$ Liber de conservanda sanitate, IX,4, p.132-133 (grifo nosso).

${ }^{37}$ Ibidem, XLV,7, p.262-263.

${ }^{38}$ Ibidem, XI,17, p.142-143; XXXI,8, p.220-221.

${ }^{39}$ Ibidem, XXXVII,8, p.234-235; XLIV,3, p.258-259.

${ }^{40}$ PATETTA, Federico - Le ordalie. Studio di storia del diritto e scienza del diritto comparato. Turim: Fratelli Bocca, 1890, p.11.
} 
benzessem os instrumentos utilizados no ordálio, rompendo assim o contágio divino que criava condições para a verdade se revelar por meio daquele método processual.

Se a analogia ocupava lugar importante em domínios do conhecimento considerados objetivos do ponto de vista atual, não seria diferente em campos de maior subjetividade, já que para o pensamento analógico o conhecimento não decorre da observação ou da demonstração, e sim da interpretação. Logo, o campo do saber no qual a Europa medieval mais investiu seus recursos intelectuais não poderia escapar à visão analógica do mundo. Como reconhece Jean-Arthur Chollet, a analogia é "um dos procedimentos mais freqüentes de conhecimento, linguagem e argumentação teológicos". ${ }^{41}$ Que o caminho analógico se impunha com naturalidade na explicação teológica fica ilustrado pela proposição de Santo Agostinho examinar por meio da razão a Assunção da Virgem, sobre a qual a Bíblia nada fala. E com efeito, ele começa a empreitada utilizando a razão lógica ao partir da premissa da condição humana de Maria para concluir que ela conheceu a morte temporal. Mas a seguir o tipo de raciocínio muda. Porque a determinação divina de toda mulher dar à luz com dor não se aplicou a Maria (pressuposto ilógico, fundado na fé), Agostinho argumenta que seria impiedade pensar que o corpo dela esteve submetido à regra de todo ser humano, que formado do pó com a morte voltará ao pó. E então conclui, por meio da razão analógica, que se a podridão corporal não atingiu a carne de Jesus, não poderia atingir a de Maria, da qual tinha sido formada. ${ }^{42}$ Procedimento deste tipo não era, claro está, exclusivo de um ou outro autor. Séculos depois de Agostinho, em linhagem teológica bem diferente, Pedro Abelardo continuou tributário da abordagem analógica. ${ }^{43}$

Como sempre ocorreu com a exegese bíblica, realizada por meio daquilo que a erudição moderna chama de silogismo tipológico, ou seja, da comparação entre Antigo e Novo Testamento teorizada por Santo Agostinho e praticada por toda a Idade Média: cada evento e cada personagem veterotestamentário antecipam eventos e personagens

\footnotetext{
${ }^{41}$ CHOLLET - “Analogie”. Em Dictionnaire de Théologie Catholique. Paris : Letouzéy et Ané, 1903, vol.I, col.1142.

${ }^{42}$ De Assumptione Beatae Mariae Virginis. Em Patrologia Latina, vol.40, col.1141-1148.

43 "O discurso analógico pode constituir uma importante chave de leitura de toda teologia abelardina", constata ALLEGRO, Giuseppe - "L'analogia nei trattati trinatari di Pietro Abelardo", em Knowledge and the sciences in medieval philosophy. Helsinki: Acta philosophica fennica, 1990, p.317.
} 
neotestamentários, estes concretizam aqueles. ${ }^{44}$ Por exemplo, os quatro rios do Paraíso terreno prefiguram os quatro Evangelhos que irrigariam o mundo; o Dilúvio, espécie de batismo universal, significa, assim como o batismo individual, o fim de uma situação de pecado e um novo nascimento. Aproximações deste tipo não resultavam apenas de exercícios hermenêuticos de especialistas. Elas estavam explicitadas pela própria Bíblia, inclusive em relação ao seu personagem central, que inverte a função do primeiro assim como em Adão todos morrem, em Cristo todos serão vivificados. ${ }^{45}$ Tertuliano no começo do século III ampliou o alcance desta relação propondo que "se Adão era figura de Cristo, o sono de Adão era a morte de Cristo, que tinha adormecido no sono de morte porque da ferida de seu flanco estava figurada a Igreja, a verdadeira mãe de todos os vivos", 46 o que significa estabelecer uma relação analógica do tipo A está para B assim como C para D e E para F.

$\mathrm{Na}$ mesma linha argumentativa, Agostinho explica a virgindade intacta de Maria em sermão pronunciado nos primeiros anos do século V: "de onde vem Maria? De Adão. De onde vem Adão? Da terra [...], portanto Maria é terra." ${ }^{, 47}$ Ora, sendo Cristo o “novissimus Adam", Ele precisava ter a mesma origem do primeiro, porém nascido de terra pura, Maria, que por consequência é analogia invertida de Eva, como indica seu difundido epíteto de "nova Eva" ou a saudação dirigida a ela, "Ave Maria!"48 Tratavase, portanto, de analogia de proporcionalidade - Cristo está para Adão assim como Maria está para Eva. Como entre Adão e Eva existe analogia de complementaridade, a mesma relação era projetada sobre os dois outros personagens. Simetricamente, o casamento de Adão e Eva prefigura o de Cristo com a Igreja. Inversamente, a expulsão dos protoplastas prefigura a Anunciação, daí a iconografia com frequência ter associado as duas cenas, caso da célebre tela (1426-1428) de Fra Angelico, hoje no Museu do Prado.

\footnotetext{
44 Speculum de Scriptura Sacra. Em Patrologia Latina, vol. 34, col.887-1040; LUBAC, Henri de Éxégèse médiévale. Les quatre sens de l'Ecriture. Paris : Cerf, 1959, vol.I, p.305-363.

451 coríntios XV,22.

${ }^{46}$ De anima, 43,10. Ed. Jan Hendrik Waszink. Leiden: Brill, 2010 (Supplements to Vigiliae Christianae, 100), p.60, linhas 12-14.

${ }^{47}$ AGOSTINHO - Sermo, 189,2. Em Patrologia Latina, vol. 38, col.1005.

481 coríntios XV,45; SANTO AMBRÓSIO, citado pela Legenda áurea, cap.2, §8, p.63; FRANCO JÚNIOR, Hilário - “Ave Eva! Inversão e complementaridade de um mito medieval” [1996]. Em IDEM Os três dedos de Adão, p.303-329.
} 
A trajetória terrena do Cristo era igualmente explicada pela analogia adâmica, como fez, seguindo longa tradição, o mais importante hagiógrafo medieval. Pelo seu arrazoado, como o primeiro homem introduziu a morte no mundo por meio do fruto de uma árvore, o segundo deveria destruir a morte sofrendo noutra árvore, a Cruz; como o primeiro pecador foi formado de terra imaculada, o redentor deveria nascer de uma virgem imaculada; como o primeiro estendera a mão para o fruto proibido, o segundo deveria estender as suas na Cruz; como o primeiro provara o sabor agradável do fruto da árvore, o segundo a caminho da sua árvore provaria o sabor amargo do fel; como o primeiro era mortal, o segundo conferiu-lhe sua imortalidade tornando-se mortal; como o primeiro foi criado e pecou numa sexta-feira de março, o segundo quis que a Anunciação e a Paixão ocorressem na mesma hora do mesmo dia do mesmo mês. ${ }^{49}$

Igualmente expressiva é a analogia entre Eva que sai do flanco de Adão - representação clássica, como na iluminura do Hexameron de Santo Ambrósio realizada em Weissenau entre 1175-1200 - e a serpente tentadora com rosto feminino que outra iluminura, esta em manuscrito profano dos arredores de 1480, sugere despontar do corpo do primeiro homem (Figuras 4-5). ${ }^{50}$

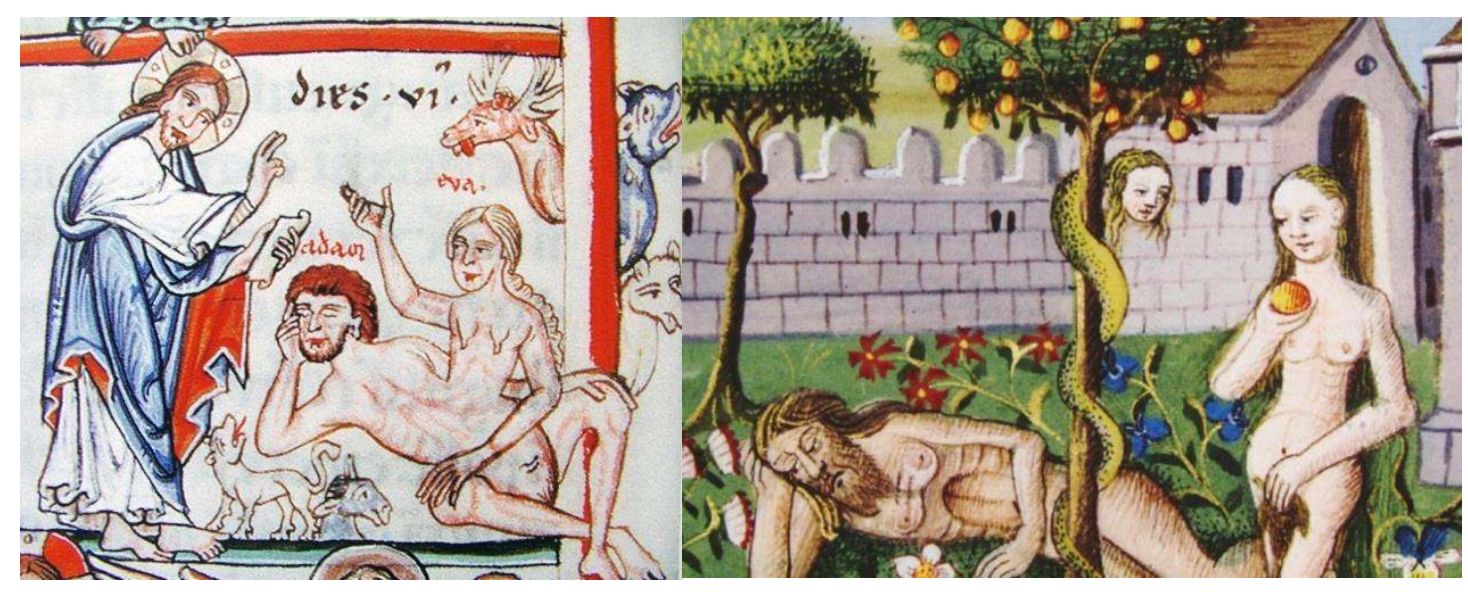

Fig. $4 \mathrm{O}$ nascimento de Eva

Fig. 5 O Pecado Original

\footnotetext{
${ }^{49}$ JACOPO DE VARAZZE - Legenda áurea, cap.2,\$8, p.63, cap.51, p.326.

${ }^{50}$ A primeira imagem é do ms. Lescalopier 30, fol.10v, hoje na Biblioteca Municipal de Amiens (reproduzida por DALARUN - Le Moyen Âge en lumière, p.270), a segunda de La Quête du Saint Graal, BnF, ms. fr. 111, fol 260v.
} 
Não é casual, portanto, que desde o começo do século III tenha surgido a analogia da Igreja com uma embarcação que ajuda os fiéis a atravessarem o mar revolto da vida terrena, ${ }^{51}$ e a partir disso a analogia específica dela com a arca de Noé (Figuras 6-7), pois ambas acolhem a criação que merece ser salva e fora das quais todos os seres animados são atingidos pela cólera divina. ${ }^{52}$ Foi com naturalidade, portanto, que a sala na qual se reunia a assembléia de cristãos passou pela sua forma de retângulo alongado a ser chamada de "nave", por influência de duas palavras gregas, vaós, naos, "templo", e vๆús, naus, "navio". Em francês, nef é atestada em 1050 para designar "barco", um século depois já indicava também o grande corredor central do templo cristão. Em português, a analogia entre a embarcação e o espaço arquitetônico surgiu no século XIII. De forma ampla, nas regiões românicas a palavra que designava a assembléia, ecclesia, impôs-se ao edifício, enquanto nas regiões germânicas foi o nome do edifício, Kirche, que passou a designar a assembléia.
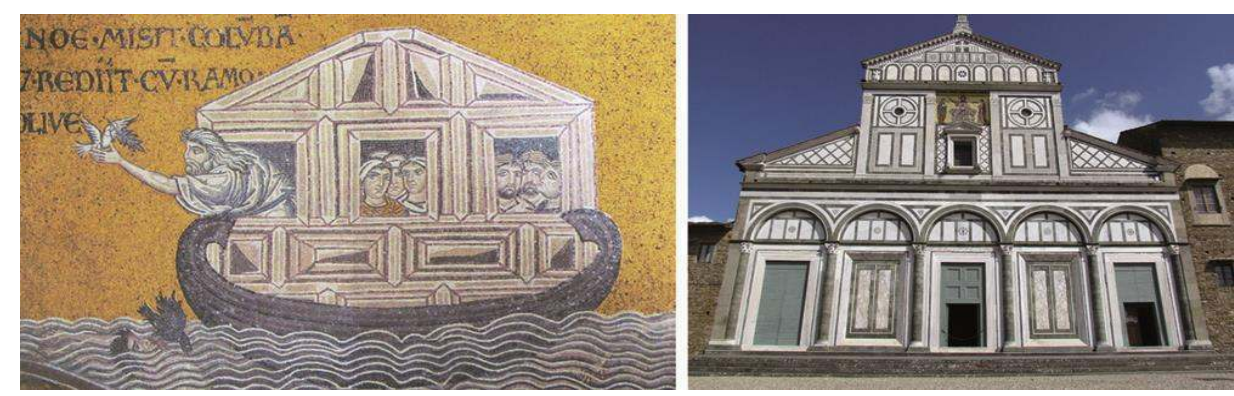

Fig. 6 A Arca de Noé literal ${ }^{53}$

Fig.7 A Arca de Noé metafórica ${ }^{54}$

51 TERTULIANO - La pudicité, XIII,20. Ed.-trad. Charles Munier. Paris: Cerf, 1993 (Sources Chrétiennes, 394), p.212-213; CIPRIANO - Correspondance, XXX,2. Ed.-trad. Louis Bayard. Paris: Les Belles Lettres, 1962, p.72-73.

52 Dentre muitos outros, TERTULIANO - De baptismo, 8. Em Patrologia Latina, vol.1, col.1317; JERÔNIMO - Dialogus contra Luciferianos, 22. Em Patrologia Latina, vol.23, col.176a; AMBRÓSIO De Noe et arca, XV,52. Em Patrologia Latina, vol.14, col.385; AGOSTINHO - La Cité de Dieu, XV,26. Ed. Bernhard Dombart e Alfons Kalb, trad. Gustave Combès. Paris: Desclée de Brouwer, 1960 (CEuvres de saint Augustin, 36), p.156-161; PEDRO DAMIANO - Carmina et preces, 153. Em Patrologia Latina, vol.145, col.961d; BRUNO DE SEGNI - Sententiae, I,2. Em Patrologia Latina, vol.165, col.879-882; HUGO DE SAINT-VICTOR - De Arca Noe moral, I,4. Em Patrologia Latina, vol.176, col.629-634; IDEM - De Arca Noe mystica. Em Patrologia Latina, vol.176, col.681-704.

${ }^{53}$ Mosaico da nave central da catedral de Monreale, parede do lado sul, entre o segundo e o terceiro arco, c. 1180 .

${ }^{54}$ Fachada da igreja de San Miniato al Monte, Florença, c. 1190. 
Sendo a liturgia cristã construída a partir de certos atos fundadores, entende-se porque "o conceito de sacramento é analógico". ${ }^{55}$ Como sete foram os dias da Criação, desde Pedro Lombardo estabeleceu-se que sete são os sacramentos (assim como os pecados capitais e os dons do Espírito Santo). Lembremos somente da eucaristia, cuja celebração foi até 1079 análoga à partilha (communio) e à comunhão (communicatio) da Última Ceia, tornando-se a partir daquela data, resultado da crescente clericalização da sociedade ocidental, análoga ao sacrifício de Cristo, em cuja carne e sangue se transubstancia (termo de meados do século XII) o pão e o vinho quando de sua consagração pelo sacerdote. Ao altar onde ocorre tal ato, desde o século VI ou VII são incorporadas relíquias de santos - metonímia por tomar a parte pelo todo - forma analógica de canibalismo, diz Alfonso di Nola, o que de certa maneira pode ter preparado os espíritos para transformar a eucaristia na maior expressão canibalesca cristã, como faz Le haut livre du Graal em meados do século XIII. ${ }^{56}$ Sendo a assembléia de fiéis o verdadeiro templo de Deus, o rito estabelece que a igreja e o altar sejam batizados e confirmados antes de a eucaristia ser ali celebrada pela primeira vez, analogamente ao que acontece com qualquer cristão.

$\mathrm{Na}$ heresiologia, as ideias religiosas que se afastavam das normas canônicas ditadas pela Igreja eram avaliadas também por contigüidade, pelo fato de serem consideradas elementos contagiosos que poderiam comprometer a saúde espiritual de toda a sociedade cristã. O bispo de Cambrai-Arras define a heresia desta última cidade, em 1025, como "veneno de uma doutrina viperina". O cronista cluniacense Raul Glaber declara por volta de 1036 que a heresia "infecta" com seu "veneno", é verdadeira “peste”. Escrevendo uns 60 anos depois dos acontecimentos, o monge Paulo de Chartres afirma que os hereges de Orléans de 1022 propagaram "nefandi herroris veneno",

55 CHAUVET, Louis-Marie - "Sacrament". Em LACOSTE, Jean-Yves - Dictionnaire critique de théologie [1998]. Paris : PUF, 2002, p.1047. Mais do que isto, o conceito cristão de mundo é sacramental devido à relação metafísica entre as coisas e Deus, diz GILSON, L'esprit de la philosophie médiévale, p.101 e 108.

56 NOLA, Alfonso di - "Reliquie". Em IDEM; ADRIANI, Maurilio e CHIAVACCI, Enrico (eds) Enciclopedia delle religioni. Florença: Vallecchi, 1973, vol.5, col.309-310; Le haut livre du Graal. Perlesvaus, I,19a. Ed. William A. Nitze e Jenkins T. Atkinson. Chicago: University of Chicago Press, 1932, vol.I, p.112, linhas 2244-2250. 
constituiram-se numa "peste". O bispo de Utrecht que se queixa em 1113 ao seu colega de Colônia das ideias de Tanchelmo, qualifica-as de "venenum perfidiae" e de "cancer". A heresia de Clemente de Bucy e seus seguidores de Soissons é chamada pelo abade Guibert de Nogent, em 1114-1117, de "cancro". Para Hildeberto de Lavardin, escrevendo em torno de 1125, Henrique de Le Mans é "peste" que "infecta" a diocese com o "veneno de sua doutrina". O mesmo monge heresiarca é chamado por uma crônica anônima de "veneno de escorpião". O abade cisterciense Bernardo de Claraval emprega, cerca 1145, este mesmo termo para designar a pregação dos cátaros, enquanto seu contemporâneo cluniacense, o abade Pedro Venerável, qualifica Pedro de Bruys e seguidores de "peste" e "veneno letal". Mais ou menos na mesma época, o abade Egberto de Schönau chama os cátaros de "péssimo veneno", “câncer”, "lepra”. Em fins do século, Guilherme de Newburgh em curto capítulo de pouco mais de três páginas da sua crônica chama nove vezes os maniqueístas de seu país de "peste" e "virus", e trata Eudes da Bretanha de "vir pestifer". ${ }^{57}$

No século XIII o uso da metáfora nosográfica prosseguiu. Em 1214 a heresia amauriciana é considerada por Guilherme, o Bretão, capelão de Filipe Augusto, como "venenosa ejus doctrina infecti". Quatro anos mais tarde Pedro des Vaux-de-Cernay, cronista cisterciense do sul francês, afirma que os cátaros eram "peste de infidelidade" que com o "veneno de sua perfídia infectaram" a província de Narbonne. Para o mais importante cronista espanhol medieval, Rodrigo Jiménez de Rada, arcebispo de Toledo, escrevendo talvez entre 1236 e 1242, os godos tinham aderido ao arianismo porque o imperador romano de então "conseguiu introduzir esse virus contagioso em tão ilustre

\footnotetext{
${ }^{57}$ Respectivamente, Acta Synodi Atrebatensis, 13. Em Patrologia Latina, vol.142, col.453c. GLABER Cronache dell'anno mille (Storie), III,VIII,26. Ed.-trad. Guglielmo Cavallo e Giovanni Orlandi. Milão: Fondazioni Lorenzo Valla / Mondadori, 1998, p.158, linhas 11-12; p.160, linha 31. PAULO DE CHARTRES - Vetus Aganus, VI,3. Em Patrologia Latina, vol.155, col.263d, 264b. Epistola Trajectensis Ecclesiae ad Fridericum episcopum Coloniensem de Tanchelmo seductore, §2, p.845c; §5, p.846a. GUIBERT DE NOGENT - Autobiographie, III,17. Ed.-trad. Edmond-René Labande. Paris : Les Belles Lettres, 1981 (Les classiques de l'histoire de France au Moyen Âge, 34), p.434. HILDEBERTO DE LAVARDIN - Epistolae, 24. Em Patrologia Latina, vol.171, col.242cd. Gesta Pontificum Cenomannensium. Em Recueil des Historiens des Gaules et de la France. Ed. Martin Bouquet e Léopold Delisle. Paris: Victor Palmé, 1877, vol.XII, p.548d, 547e. BERNARDO DE CLARAVAL - Sermones in Cantica Canticorum, LXXXIV,I,1. Ed. Jean Leclercq, Charles Talbot e Henri Rochais. Roma: Editiones Cistercienses, 1958 (S. Bernardi opera, 2), p.179, linha 4. PEDRO, O VENERÁVEL - Contra Petrobrusianos hereticos, 1. Ed. James Fearns. Turnhout: Brepols, 1968 (CCCM 10), p.3, linhas 11 e 19. EGBERTO DE SCHÖNAU - Sermones contra catharos, I. Em Patrologia Latina, vol.195, col.13b. GUILHERME DE NEWBURGH - Historia Rerum Anglicarum. Ed. Richard Howlett. Wiesbaden: Kraus, 1964 (Rerum Britannicarum Medii Aevi Scriptores, 82-I), II,13, p.131-134; I,19, p.60.
} 
povo". Seu colega francês do começo da segunda metade do século, Guilherme de Puylaurens, fala em "febris heretica". Para o concílio de Mogúncia de 1259, as beguinas são "pestíferas”. Por volta de 1267 Jacopo de Varazze qualifica o catarismo de "peste diabólica". Bernardo Gui, célebre inquisidor do século XIV, diz que Geraldo Segarelli "infundens virus pestiferum". 58

Também na religiosidade, tanto oficial como popular, as relações analógicas ocupavam lugar de destaque. O princípio da eficácia simbólica era a base tanto dos filactérios e conjuros reprovados pelo clero cristão, quanto das relíquias e orações defendidas por ele. A fronteira entre a crença legítima e aquilo que a Igreja taxou pejorativamente de superstições era apenas ideológica, daí, aliás, ter flutuado ao longo da história. Como nota Jean-Claude Bologne, qualquer tentativa de estabelecer uma distinção entre magia e religião "disfarça mal a semelhança das concepções e das técnicas". 59 Se por teoria construída a posteriori a magia busca ganhos materiais e o milagre salvação espiritual, na vivência medieval vários atos considerados oficialmente mágicos tentavam resgatar o indivíduo do âmbito demoníaco e talvez a maioria dos milagres propiciasse cura, alimentação e proteção terrenas mais do que bens espirituais.

Dos dois lados da delimitação ideológica todas as expressões religiosas ocorriam (e ocorrem) por mecanismos analógicos. O do contágio, por exemplo. Em abril de 1050, em Benevento, deu-se o milagre de uma paralítica ser curada ao beber a água com que o papa Leão IX, então em visita à cidade, fizera as santas abluções; no começo do século XII, um relato registra a ignorância e idolatria daqueles que bebiam a água do banho do herege Tanchelmo de Antuérpia pela suposta virtude dela. ${ }^{60}$ Duplicidade semelhante

\footnotetext{
${ }^{58}$ GUILHERME, O BRETÃO - Gesta Philippi Augusti, 153. Ed. François Delaborde. Paris : Société de l'Histoire de France, 1882, vol.I, p.231. PEDRO DES VAUX-DE-CERNAY - Hystoria Albigensis, I,6, p.6; I,12, p.12. RODRIGO JIMÉNEZ DE RADA - Historia de rebus hispanie sive historia gothica, II,1. Ed. Juan Fernández Valverde. Turnhout: Brepols, 1987 (CCCM 72), p.40, linhas 31-32. GUILHERME DE PUYLAURENS - Chronique, 2. Ed.-trad. Jean Duvernoy. Toulouse : Le Pérégrinateur, 1996, p.36. Concilium Provinciale Mongutinum, em Sacrorum conciliorum nova et amplissima collectio. Ed. Gian Domenico Mansi. Paris: H. Welter, reed. 1903, vol.23, col.998c. JACOPO DE VARAZZE - Legenda áurea, cap.61, §4, p.390. BERNARDO GUI - Manuel de l'inquisiteur. Ed.-trad. Guillaume Mollat. Paris : Les Belles Lettres, 2006 (Les classiques de l'histoire de France au Moyen Age, 44), vol.II, apêndice I,1, p.66.

59 SCHMITT, Jean-Claude - História das superstições [1988]. Lisboa: Publicações Europa-América, 1997, p.13; BOLOGNE - Da chama à fogueira, p.201.

${ }^{60} \mathrm{La}$ vie du pape Léon IX, II,14. Ed. Michel Parisse, trad. Monique Goullet. Paris: Les Belles Lettres, 1997 (Les classiques de l'histoire de France au Moyen Âge, 38), p.96-97; Epistola Trajectensis Ecclesiae ad Fridericum episcopum Coloniensem de Tanchelmo seductore, §3, p.845e.
} 
envolvia todo recém-nascido. Na igreja, pela liturgia do batismo ele precisava ter contato com a água benta e o sal, pela paraliturgia descrita por um franciscano alemão do século XIV deveria tocar com os pés nus o altar, com a boca a corda do sino, com a mão a Bíblia, com o rosto a toalha do altar. Na casa, ocorria um rito popular cuja diferença eram os objetos que garantiam boa sorte ao bebê, envolvido pela palha com a qual se havia limpado o forno, esfregado com cinza, tocado por orelha de lebre e pata de toupeira colocadas no berço. ${ }^{61}$

Embora opostos ideologicamente, o milagre pagão que é a magia e a magia cristã que é o milagre possuem estrutura comum - o poder da palavra, no qual se deposita a esperança de eficácia seja da invocação seja da oração, como deixam entrever os próprios termos. O primeiro é pedido manifestado "por meio da voz" - in+ vocatione no latim clássico, im+ precatio na língua dos séculos I-II - fosse ele positivo, benedictio, ou negativo, maledictio, ou seja, o ato de dizer alguma coisa propiciaria sua ocorrência. O segundo termo é mais interessante, pois em sentido próprio oratione não possuía carga valorativa, era simplesmente "faculdade de falar", "linguagem”, "palavra", "discurso", "prosa", "estilo", acepções das quais o cristianismo derivou a de palavra dirigida a Deus, "prece". Apesar de a erudição moderna ter várias vezes atribuído à primeira uma qualidade cominatória e à segunda uma pleiteante, não se tratavam na Europa medieval de formas impermeáveis. Desde fins do século I ou princípios do II invocare tinha a acepção de "pedir socorro", preces além de "súplica" significava ainda imprecatio, "maldição". Existiam invocações em tom de solicitação e podia-se dirigir preces extorsivas aos santos ou à Virgem. ${ }^{62}$ Dito de outra forma, o denominador comum entre invocação e oração é o mecanismo metafórico que se propõe a interpretar e a intervir na vasta grade semiótica que é o universo, deslocando os homens e os fenômenos da esfera da natureza para a da sobrenatureza.

Isto era possível graças ao mecanismo da contiguidade, ilustrado pelo campo semântico de convenientia, termo do latim clássico para "afinidade natural", "conjunção", "harmonia", substantivo do verbo convenire, etimologicamente "vir junto", em sentido figurado "assemelhar-se". Quer dizer, as coisas conveniens-entis são semelhantes e

\footnotetext{
${ }^{61}$ FREI RUDOLFO - De Officio Cherubyn. Ed. Adolf Franz. Theologische Quartalschrift. Tübingen. 88 (1906), p.419-422, citado por BOLOGNE - Da chama à fogueira, p.106-107.

${ }^{62}$ Legenda áurea, $3, \S 9$, p.74-75; 126,\$4, p.752-753.
} 
tendem a se aproximar, a convergir, a concordar (como ocorre entre irmãos), ${ }^{63}$ a se harmonizar (a alma e o corpo juntam-se por convenientia), ${ }^{64}$ a se reunir (conventus designa uma assembléia de fiéis, de monges, de comerciantes, e mesmo união carnal), ${ }^{65}$ num complexo jogo de nuanças, resignificações e complementações. Nas palavras de Foucault, convenientia é "similitude das propriedades porque neste continente natural que é o mundo, a vizinhança não é uma relação exterior entre as coisas mas o sinal de um parentesco, ainda que obscuro". 66

No pensamento analógico a forma importa mais que o conteúdo. Podia-se favorecer o parto evocando santas (sobretudo Ana, Maria e Isabel) que deram à luz de maneira feliz. Podia acontecer um milagre por imitação de uma passagem bíblica: quando durante uma viagem de barco pelo Reno uma mulher pediu a intervenção de Hildegarda de Bingen a favor do filho cego, a santa lembrou-se das palavras do Senhor "vá à piscina de Siloé e lave-se", então com a mão esquerda pegou um pouco de água do rio e jogou-a sobre os olhos do garoto enquanto com a mão direita o benzia. ${ }^{67}$ Mesmo um objeto prosaico, a ferradura de cavalo cujo uso se difunde a partir do século XII, derivava de seu formato análogo à lua crescente, símbolo de fertilidade, e ao C inicial do nome Cristo - a suposta capacidade de propiciar boa sorte. Esta função passaria da forma para a matéria por meio de procedimento do tipo sinedóquico (isto é, que desloca o significado para além dos limites do conteúdo conceptual): o fato de alguém encontrar qualquer peça de ferro era considerado bom sinal, como testemunha um texto literário de fins do século $\mathrm{XV}$. ${ }^{68}$

Como qualquer sociedade, a da Europa medieval estava fundada na memória coletiva que reune e preserva eventos significativos para a quase totalidade de seus membros, assim justificando e legitimando os diferentes tipos de relações entre eles. Lembrar é mais que uma atividade neurobiológica, é ato analógico. Se Paul Valéry afirmaria que "tudo que não é memória é analogia”, Santo Agostinho parece ter mais razão ao fundir

\footnotetext{
63 Vita Johannis Abbatis Reomaenses, 7. Ed. Bruno Krush. Hanover: Hahniani, 1896 (Monumenta Germaniae Historica. Scriptorum rerum Merovingicarum, 3), p.509, linha 27.

${ }^{64}$ MAMERTINO - De statu animae, II,7. Ed. August Engelbrecht. Viena: C. Geroldi Filium, 1885 (Corpus Scriptorum Ecclesiasticorum Latinorum, 11), p.120, linha 17.

65 AMBRÓSIO - Enarrationes in psalmos, XXXVII,8. Em Patrologia Latina, vol.14, col. 1013a; AGOSTINHO - Contra Julianum, IV,8,49. Em Patrologia Latina, vol.44, col.763.

${ }^{66}$ A palavra e as coisas, p.74.

${ }^{67}$ Vita Sanctae Hildegardis, III,18. Ed. Monica Klaes. Turnhout: Brepols, 1993 (CCCM 126), p.55.

${ }^{68}$ SALLES, Catherine - "Le fer à cheval donne du bonheur", em Á l'origine des superstitions, número temático de Historia Spécial. Paris. 6 (2012), p.20; ECO, "Metáfora", p.203; Les évangiles des quenouilles. Ed. Madeleine Jeay. Paris: Vrin, 1985, p.125.
} 
os dois termos em um mesmo conjunto, ao reconhecer que "teço" (contexo) experiências e crenças das quais por semelhança (similitudines) extraio outras imagens do passado e do futuro, tudo como se fosse do presente. ${ }^{69}$ Daí porque, além da compreensão, a analogia entra na preservação do conhecimento adquirido, como insistem os tratados medievais de mnemônica. A própria memória é objeto de analogia, sendo considerada lugar no qual as lembranças estão organizadas espacialmente, o que as línguas vernáculas guardam na metáfora "aprender/saber de cor”, isto é, no coração. Por isso mesmo, o maior problema da memória não é o esquecimento (às vezes necessário, como São Bernardo intuiu e Freud explicará), e sim a desordem. ${ }^{70}$

Contra a desordem na memória coletiva, que poderia colocar em risco a sobrevivência de um grupo social ou mesmo da sociedade inteira, certos indivíduos filtravam (conforme os interesses do segmento representado) e registravam (de forma oral ou escrita, dependendo do público-alvo) as recordações julgadas pertinentes. E faziam-no recorrendo de maneira quase inconsciente, automática, às analogias devido à capacidade delas de não somente reter o transcorrido como de vislumbrar o sequente. Do ponto de vista medieval, memoria é o local de onde se pode a partir das coisas passadas contemplar por analogia as coisas vindouras: "futura per preterita similitudinarie contemplamur". ${ }^{71}$ Dentre muitos outros casos, lembremos apenas dois.

Justificando os excessos da Cruzada enviada contra os hereges do sul francês, em 1218 um cronista afirma que assim como a destruição de Jerusalém tinha ocorrido 42 anos após a paixão do Senhor, o massacre de Béziers (sete mil mortos na igreja da Madalena) aconteceu 42 anos depois do assassinato do visconde local. ${ }^{72} \mathrm{Na}$ hagiografia composta por um clérigo da catedral de Lisboa, talvez entre 1175 e 1185, afirma-se que ao retirar um osso do corpo santo que ajudou a resgatar, um indivíduo perdeu a visão, recobrada quando devolveu a relíquia, quer dizer, o relato percebe certa conexão entre coisas aparentemente distintas, uma parte do corpo do santo morto e outra parte do corpo do

69 VALÉRY - Cahiers 1. Ed. Judith Robinson-Valéry. Paris: Gallimard, 1989 (Pléiade, 242), vol.I, p.1217; AGOSTINHO - Confessions, X,8,14. Ed. Martin Skutella, trad. Eugène Tréhorel e Guilhen Bouissou. Paris: Desclée de Brouwer, 1962 (CEuvres de saint Augustin, 14), p.166-167.

${ }^{70}$ CARRUTHERS, Mary - The book of memory: a study of memory in medieval culture. Cambridge: CUP, 1990; IDEM - The craft of thought: meditation, rhetoric and the making of images, 400-1200. Cambridge: CUP, 1998.

${ }^{71}$ BONCOMPAGNO - Rhetorica novissima, VIII,1, p.275.

${ }^{72}$ PEDRO DES VAUX-DE-CERNAY - Hystoria Albigensis, 91, p.92-93. 
fiel vivo. Conexão que não deve causar estranheza, pois como observa Gilson toda analogia exerce dupla função, ao mesmo tempo unificadora e separadora, já que de um lado o análogo está sempre ligado ao seu princípio por ser um análogo, e de outro lado está separado dele por não ser mais do que um análogo. ${ }^{73}$

O mesmo raciocínio aplicava-se, além dos eventos que hoje chamaríamos de microhistória, também a uma visão alargada, a das idades do mundo, que se pode esboçar assim:

\begin{tabular}{|l|l|l|l|l|l|}
\hline IDADE & METAL & IDADE DO HOMEM & PARTE DO & HISTÓRIA & $\begin{array}{l}\text { HORA DO } \\
\text { DIA }\end{array}$ \\
\hline Primeira & Ouro & Lactância & Cabeça HUMANO & De Adão a Noé & Prima \\
\hline Segunda & Prata & Infância & Peito & De Noé a Abraão & Terça \\
\hline Terceira & Bronze & Adolescência & Ventre & De Abraão a Davi & Sexta \\
\hline Quarta & Ferro & Juventude & Coxas & $\begin{array}{l}\text { De Davi ao cativeiro da } \\
\text { Babilônia }\end{array}$ & Nona \\
\hline Quinta & Chumbo & Velhice & Pernas & $\begin{array}{l}\text { Do cativeiro da Babilônia ao } \\
\text { nascimento de Cristo }\end{array}$ & Vésperas \\
\hline Sexta & Argila & Decrepitude & Pés & $\begin{array}{l}\text { Do nascimento de Cristo ao } \\
\text { Juízo Final }\end{array}$ & Completas \\
\hline
\end{tabular}

Quadro 1. As idades do mundo

Se toda literatura é estruturalmente analógica, a da época medieval desenvolveu um tipo particular, baseado na analogia especular que explicava reciprocamente o mundo celeste e o mundo terreno - "assim na Terra como no Céu", diz a oração. E explicava igualmente o homem (que é espelho de todas as maravilhas divinas, "homo speculum omnium miraculorum est dei") ${ }^{74}$ e seu comportamento social (no qual os semelhantes aplaudem os semelhantes, "similia similibus applaudunt") 75 . É por isso que a esposa de

${ }^{73}$ MESTRE ESTÊVAO - Miracula S. Vincentii, 1.1. Ed.-trad. Aires Augusto Nascimento e Saul António Gomes. Lisboa: Didaskalia, 1988, p.34-35; GILSON, L'esprit de la philosophie médiévale, p.97, n.1.

${ }^{74}$ HILDEGARDA - Causae et curae, II, p.65, linhas 24-25.

75 PEDRO COMESTOR, Historia scholastica, Liber Genesis, col.1072; GERVÁSIO DE TILBURY Otia imperialia, I,15. Ed.-trad. Shelagh E. Banks e James W. Binns. Oxford: Clarendon, 2002, p.86. 
Santo Aleixo considerava-o "meu espelho" ${ }^{76}$ Como se acreditava que o comportamento do indivíduo revela sua alma, pretendia-se agir sobre esta pela disciplina, pelo conhecimento, pelo exemplo, educando enfim, daí a literatura de formação adotar aquela palavra. O "espelho do príncipe" pretendia fornecer orientação e passar valores considerados indispensáveis para quem ocupava postos de comando. Como espelho do espelho, educando pelo contraste, existiu ao menos um "espelho dos tolos" - redigido em fins do século XII por um monge de Canterbury, Nigel de Longchamp - que insistia serem sábios aqueles que se corrigem ao ver nos outros seus próprios erros, enquanto tolos são aqueles que não retêm tais imagens, não percebem que elas são reflexos deles mesmos, e por isso permanecem tolos. ${ }^{77}$

Apesar de ligada à cultura erudita, aquele tipo de literatura expressava um comportamento, um sistema de valores, uma visão de mundo, comuns a todos os segmentos da sociedade medieval. Mais do que isso, ele exteriorizava, de acordo com os instrumentos culturais então disponíveis, o fenômeno psicossocial de todas as épocas pelo qual o governante é definido somente em relação ao súdito, assim como o sacerdote em relação ao leigo, o senhor ao escravo, o nativo ao estrangeiro, o homem à mulher, o adulto à criança. ${ }^{78}$ É fato que na tentativa de se ver, descobrir, autoconhecer, o ser humano é sempre obrigado a se considerar a partir da observação do outro. Inclusive, na civilização medieval, de objetos ou animais. No primeiro caso estava, por exemplo, a charrua como espelho empregado para alcançar a essência existencial e social da mulher, comparada à terra cultivada por aquele instrumento e que recebe a semente do esposo ("nam femina est nunc velut terra aratro arata et semen viri suscipit"). No segundo caso, o difundido jogo de palavras servus-cervus era usado para atribuir a este animal caráter cristológico, de animal de sacrifício que por amor serve

\footnotetext{
${ }^{76}$ Legenda áurea, 89, p.542.

77 NIGELLUS DE LONGCHAMP - Speculum Stultorum. Ed. John H. Mozley e Robert R. Raymo. Berkeley: University of California Press, 1960 (English Studies, 18).

${ }^{78}$ Existiria mesmo uma fase da formação do ego que seria o "estágio do espelho", no qual a aquisição da auto-imagem se faz apenas a partir da mediação da imagem e do olhar do outro: LACAN, Jacques - "Le stade du miroir comme formateur de la fonction du Je", em IDEM - Ecrits. Paris: Seuil, 1966, p.89-97.
} 
aos homens. ${ }^{79}$ Entre os verba e as res havia uma relação profunda, um elo invisível, metafísico. Elo explicativo e explicável por ser analógico.

Daí porque outro campo no qual se exercia aquele tipo de raciocínio afetivo era a etimologia. Não é casual que imediatamente antes do capítulo dedicado a ela, Isidoro de Sevilha tenha reservado um à analogia, pois esta é que permite e fundamenta aquela. Isto diz bem da importância do pensamento analógico, na medida em que, do ponto de vista cristão medieval, a etimologia explica tanto a origem como o sentido das coisas. A grande enciclopédia isidoriana - significativamente intitulada Etymologiae - foi definida na dedicatória ao rei Sisebuto como "misi opus de origine quarundam rerum", minha obra a respeito da origem de certas coisas. Este significado vinha desde o século

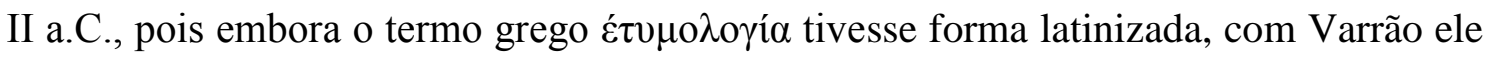
passou a ser traduzido por origo. Ou seja, o termo técnico gramatical foi vertido por um termo corrente derivado do verbo orior, "levantar", "nascer", aplicado à aparição de uma coisa (como o sol, daí oriens, "oriente") ou pessoa (como na expressão solum in quo ortus es, a terra na qual nasceste).

Contudo, foi com o cristão Isidoro que a etimologia se tornou etiologia. Deixou-se o campo do discurso racional (logos) sobre a verdade (étymon) pelo campo da origem das palavras - "etymologia est origo" - o que segundo o bispo de Sevilha permite alcançar o valor essencial delas (vis verbi). Por exemplo, quando ele explica a denominação dada aos animais por Adão, afirma que este a fez seguindo a "condicionem naturae" dos nominados. Dito de outra forma, a denominação de cada animal manifesta suas características essenciais, inclusive no caso do homem - homo vem de humus. ${ }^{80}$ A lição isidoriana faria sucesso ao longo da Idade Média. Dentre muitos outros autores, Marbode, bispo de Rennes em 1096-1123, afirma que “a coisa designada pelo nome determina o nome. Por isso devemos procurar a natureza das coisas para então podermos saber a verdade acerca do nome". 81

\footnotetext{
${ }^{79}$ Respectivamente, HILDEGARDA - Causae et curae, II, p.104, linhas 33-34; DUCHET SUCHAUX, Gaston e PASTOUREAU, Michel - Le bestiaire médiéval. Dictionnaire historique et bibliographique. Paris: Le Léopard d'or, 2002, p.40.

${ }^{80}$ As citações de Etimologías são, na sequência : I,29,1, vol.I, p.320; XII,1,1, vol.II, p.56; I,29,3, p.322.

${ }^{81}$ MARBODE - Carmina varia. Em Patrologia Latina, vol. 171, col.1671c.
} 
Sobretudo esclarecedora é a etimologia onomástica, pois o nome é o primeiro dos atributos das pessoas, ${ }^{82}$ como se percebe no Novo Testamento (Simão torna-se Pedro porque é a pedra da Igreja; Saulo adota o nome Paulo porque é pouco, é o menor dos apóstolos), ${ }^{83}$ em muitos pensadores medievais, ${ }^{84}$ na cultura vulgar da época (um provérbio do século XV garante que "au surnom cognoit-on l'homme"). ${ }^{85}$ A mais difundida suma hagiográfica medieval utiliza abundantemente a etimologia analógica para explicar o nome dos santos a partir de suas virtudes e, inversamente, para explicar estas em função daquele. Nicolau vem de nikós, "vitória" e de laos, "povo", indicando assim "vitória do povo" ou, mais apropriadamente, "vitória sobre os vícios populares e vis". Cristina significa "ungida com crisma" por ter sido bálsamo odorífero nos seus atos e óleo de devoção na sua alma. Bernardo correspondia bem às características do santo, cujo nome deriva de ber, "fonte", e nardus, planta humilde, ardente e perfumada. Mateus quer dizer "grande para Deus" por ser formado de magnus, "grande", e Theos, "Deus", ou então é "mão de Deus" por vir de manus, "mão", e Theos. ${ }^{86}$

Porque o nome de cada santo revela sua verdade profunda, a Igreja, melhor institucionalizada a partir do século XII, estimulou a utilização de nomes de santos por parte dos fiéis fundando-se no antigo princípio do "bonum nomem, bonum omem". Esta revolução antroponímica estendeu-se por toda Europa cristã, ainda que com ritmos, intensidades e modalidades próprias a cada região. Em Portugal ela parece ter começado já em fins do século XI, na França centro-setentrional e na Inglaterra o processo arrancou logo a seguir, na Toscana a vitória do novo sistema deu-se no século XIII. À medida que a antroponímia cristã se impunha e restringia o repertório onomástico geral, aumentando bastante o número de pessoas com o mesmo nome, surgiu a necessidade de fatores de individuação. Para tanto recorreu-se a outro mecanismo analógico, a contiguidade, que podia ser criação interna ou externa ao grupo interessado.

\footnotetext{
${ }^{82}$ CÍCERO - De l'invention, I,XXIV,34, p.91.

${ }^{83}$ Mateus XVI,18; 1 coríntios XV,9.

${ }^{84}$ CURTIUS, Ernst Robert - Literatura européia e Idade Média latina [1948]. São Paulo: Edusp / Hucitec, 1996, p.607-611.

${ }^{85}$ LE ROUX DE LINCY, Antoine-Jean-Victor - Le livre des proverbes français [1842]. Paris : Hachette, 1996, p.486.

${ }^{86}$ Legenda áurea, 3, p.69; 93, p.558; 115, p.682; 133, p.778.
} 
Por iniciativa do próprio indivíduo ou de sua família adotou-se em toda parte, talvez mais frequentemente e por mais tempo na Península Ibérica, a solução patronímica. ${ }^{87}$ Quer dizer, ao nome próprio juntou-se um segundo antropônimo derivado do paterno, prática que após algumas gerações poderia transformar aquele simples referente "Jacquard" assinalava tão somente que se era filho ou filha de um Jacques, "Pierini" de um Piero, "Rodriguez" ou "Rodrigues" de um Rodrigo, etc - em cognato. Mas a construção daquilo que acabaria por ser o moderno nome de família ocorreu majoritariamente por atribuição externa ao grupo. A Antiguidade já tinha se servido da atividade produtiva como identificação consanguínea: lembrando as origens agrárias da sociedade romana, importantes famílias eram designadas por leguminosas, como Fabius, vindo de faba, "fava"; Lentulus, de lenticula, "lentilha"; Pisa, de pisa, "ervilha"; Cícero, de cicer, "grão-de-bico".

Na Cristandade medieval, igualmente, o nome de família provinha com muita frequência da identificação antonomástica de um antepassado cujos traços físicos ou morais tinham sido analogizados com o de ave (Loiseau, Colombo, Cuervo, Perdigão, Swallow, Adler, etc), animal doméstico (Cheval, Gatto, Cordero, Coelho, Bull, Kuh, etc) ou selvagem (Leloup, Orso, Léon, Raposo, Tiger, Einhorn, etc), objeto possuído (Forge, Spada, Castillo, Machado, Bridge, Mühle, etc), atividade praticada (Boulanger, Tessitore, Guerrero, Pedreiro, Smith, Pastor, etc), condição social (Chevalier, Moro, Casado, Franco, Pilgrim, Küster, etc), acidente geográfico da região de origem (Dubois, Montagna, Valle, Ribeiro, Rock, Wiese, etc), a região natal ou adotiva (Lebreton, Lombardo, Gallego, Couto, Irish, Wald, etc).

A sabedoria paremiológica, tão difundida nas sociedades tradicionais, também recorria abundantemente às analogias, das quais parece, aliás, ter retirado muito de seu alcance social. Basta folhear ao acaso os florilégios e os Libri proverbiorum, comuns a partir do século XI, para se dar conta do uso recorrente que eles faziam de metáforas, antíteses, jogos de palavras e outras estruturas analógicas. Provavelmente devido a isto é que provérbios são realidade antropológica mais do que histórica. Lembremos somente dois

${ }^{87}$ GONÇALVES, Iria - “O nome”. Em MATTOSO, José (dir.) - A história da vida privada em Portugal. Lisboa: Círculo de Leitores, 2011, p.208, informa que em Portugal em meados do século XII tal modalidade de identificação foi empregada por $65 \%$ dos indivíduos, proporção que cresceria nos séculos seguintes. Ademais, esta estratégia de identificação preponderou até fins do século XV (p.210). 
casos, deixando de lado suas diversas variantes. O sono como irmão/ primo/imagem da morte é atestado em autores antigos (Hesíodo, Homero, Pausânias, Xenofontes, Cícero, Virgílio, Ovídio), patrísticos (Clemente de Alexandria, Epifânio, Gregório de Nissa, Gregório de Nazianzo, João Damasceno, Tertuliano, Ambrósio, Agostinho) e medievais (Amalário, Honório Augustodunense). ${ }^{88}$ Também muito difundida era a analogia que pensava a sociedade de maneira antropomórfica, comparando o governante à cabeça e os súditos aos membros, como fizeram dentre outros João de Salisbury no século XII e uma coletânea de exempla no século XIV ("li chiefs ne puet estre sains quant li membre sont enferme par defaut de gouvernation, ne li membre ne puent estre sain dont li chiefs est mallades"). ${ }^{89}$

Para o homem medieval o pensamento analógico era, por tudo que acabamos de ver, determinante no seu saber, agir, sentir. O ponto de partida e, ao mesmo tempo, a síntese disto estava na percepção de que o universo era uma imensa rede de correspondências, de relações micro-macrocósmicas. Naquilo que chamamos atualmente de ciências naturais os homens da Europa medieval, prolongando seus antecessores da Antiguidade greco-latina, aceitavam a existência de conexões profundas entre pedras, metais e signos zodiacais. O papa Gregório Magno relacionou as pedras que formam a Jerusalém celeste descrita no Apocalipse e as ordens angelicais (a sardônia associada aos serafins, o topázio aos querubins, e assim por diante). O ser humano era visto como zodiacal na medida em que cada parte de seu corpo é regida por um signo do zodíaco, como mostram diversas imagens, sobretudo do século XV. Na definição de Umberto Eco, o

\footnotetext{
${ }^{88}$ RAPALLO, Umberto - "Il sonno della morte: un problema interlinguistico". Aion. Nápoles. 16 (1994), p.11-32; TOSI, Renzo - Dictionnaire des sentences latines et grecques [1991], nº1027. Grenoble: Jérôme Millon, 2010, p.754-756.

${ }^{89}$ JOÃO DE SALISBURY - Policraticus, V,2. Em Patrologia Latina, vol.199, col.540 bd; Ci nous dit, 164,9. Ed. Gérard Blangez. Paris : Picard, 1979, vol.I, p.160 (cf. também 251,17, p.219 : "qui a le chief enferme, tuit li membre l'en deullent", e Proverbes français antérieurs au XV siècle, nº43. Ed. Joseph Morawski. Paris: Edouard Champion, 1925, "cui li chies dieut, tuit li membre li falent").
} 
universo é um tecido rizomático no qual todo ser "funciona como sinédoque ou metonímia do Uno".90

Nesta cosmologia que coloca o homem no ponto central, ele é considerado uma condensação do universo - minor mundus - como explicam dentre outros os influentes Honório Augustudonense entre 1110 e 1139 e Vicente de Beauvais em 1244. ${ }^{91}$ Hildegarda de Bingen, em 1163, leva as relações analógicas mais longe - o universo apresenta características humanas (o sol é a luz de seus olhos, o vento o som de seus ouvidos, o ar seu odor, o orvalho seu paladar), pelo menos alguns homens são análogos ao universo (Abel é como a lua, Noé o sol, Abraão os planetas, Moisés as estrelas, os profetas os quatro pontos cardinais). ${ }^{92}$ Os pontos essenciais desta visão estrutural e estruturante podem ser esquematizados, à guisa de conclusão, no quadro abaixo: ${ }^{93}$

\footnotetext{
${ }^{90}$ ECO, "Metáfora", p.222.

${ }^{91}$ Respectivamente, Imago Mundi, I,87. Ed. Valerie Flint. Archives d'histoire doctrinale et littéraire du Moyen Âge. Paris. 57 (1982), p.80; Speculum historiale, I,30, em Speculum quadruplex. Douai: Balthazar Belleri, 1624, vol.IV, p.12a. FINCKH, Ruth. Minor Mundus Homo. Studien zur Mikrokosmos-Idee in der mittelalterlichen Literatur. Göttingen: Vanderhoeck und Ruprecht, 1999, p.24-87, estabelece uma tipologia de 21 tipos de microcosmos.

${ }_{92}^{2}$ Epistolarium, XVR. Ed. Lieven Van Acker. Turnhout: Brepols, 1991 (CCCM 91), p.34-36.

${ }^{93}$ Como toda tentativa de síntese, este quadro deixa de lado informações e interpretações divergentes fornecidas por algumas fontes primárias, nem por isso menos importantes. É o caso, por exemplo, de certas variantes nos atributos dos signos zodiacais, cuja coincidência com as constelações que lhes deram os nomes foi se perdendo com a precessão dos equinócios.
} 


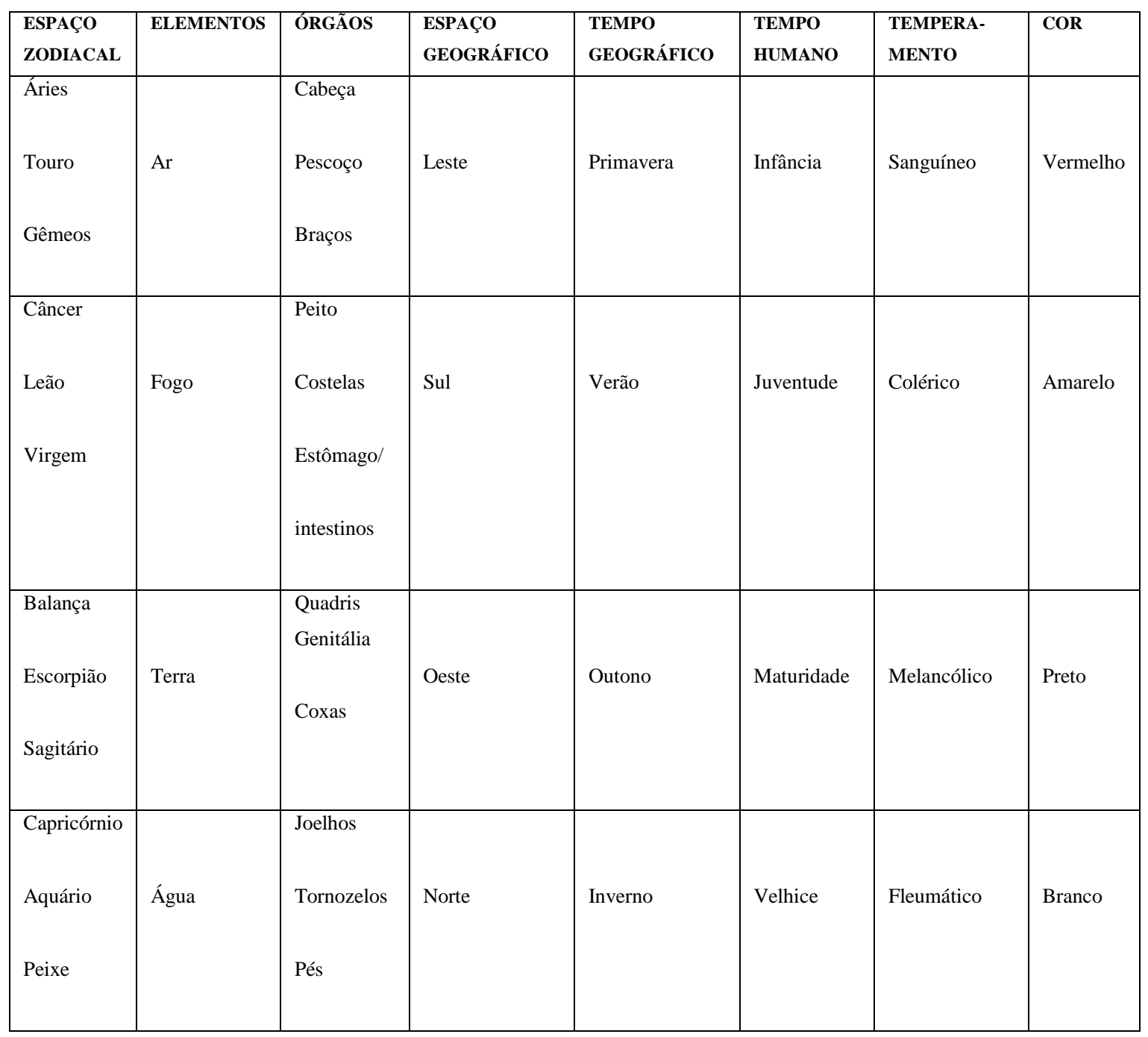

Quadro 2. Correspondências micro-macrocósmicas 


\section{FONTES E BIBLIOGRAFIA}

As obras citadas somente uma vez no presente trabalho estão referenciadas de forma completa nas notas correspondentes. As demais, que nas notas aparecem abreviadamente, estão listadas a seguir.

\section{Fontes primárias}

BONCOMPAGNO DA SIGNA - Rhetorica novissima. Ed. Augusto Gaudentio. Bolonha: Libreria dei Fratelli Treves di Pietro Virano, 1892 (Bibliotheca Iuridica Medii Aevi, 2).

CICERO - De l'invention. Ed.-trad. Guy Achard. Paris : Les Belles Lettres, 1994. ISBN 2-251-01381-4

Epistola Trajectensis Ecclesiae ad Fridericum episcopum Coloniensem de Tanchelmo seductore. Ed. Sebastian Tengnaghel. Em Acta Sanctorum, junii I. Bruxelas: Culture et Civilisation, reed. 1969, p.845-847.

HILDEGARDA DE BINGEN - Causae et curae. Ed. Paul Kaiser. Leipzig: Teubner, 1903.

HILDEGARDA DE BINGEN - Liber divinorum operum. Ed. Albert Derolez e Peter Dronke. Turnhout: Brepols, 1996 (Corpus Christianorum Continuatio Medievalis 92). ISBN 2-503-03921-9

ISIDORO DE SEVILHA - Etimologías. Ed. Wallace Martin Lindsay, trad. José Oroz Reta e Manuel-Antonio Marcos Casquero. Madri: BAC, 1982. ISBN 84-220-1071-2.

JACOPO DE VARAZZE - Legenda áurea. Ed. Theodor Graesse, trad. Hilário Franco Júnior. São Paulo: Companhia das Letras, 2003. ISBN 85-359-0367-4.

Obras médicas de Pedro Hispano. Ed-trad. Maria Helena da Rocha Pereira. Coimbra: Universidade, 1973. 
Patrologia Latina. Ed. Jacques-Paul Migne. Paris: Migne, 1844-1865, 221 volumes.

PEDRO DES VAUX-DE-CERNAY - Hystoria Albigensis. Ed. Pascal Guébin e Ernest Lyon. Paris: Honoré Champion, 1926.

\section{Fontes secundárias}

BOLOGNE, Jean-Claude - Da chama à fogueira. Magia e superstição na Idade Média [1993]. Trad. Fátima Gaspar e Carlos Gaspar. Lisboa: Publicações Dom Quixote, 1998. ISBN 972-20-1524-9.

DALARUN, Jacques (dir.) - Le Moyen Âge en lumière. Paris: Fayard, 2002. ISBN 2213-61397-4.

ECO, Umberto - "Metáfora”. Em Enciclopédia Einaudi. Trad. Maria Bragança. Lisboa: Imprensa Nacional-Casa da Moeda, 1994, vol.31, p.200-246. ISBN 972-27-0660-8.

FOUCAULT, Michel - As palavras e as coisas. Uma arqueologia das Ciências Humanas [1966]. Trad. António Ramos Rosas. Lisboa: Edições 70, 2005. ISBN 97244-0531-1.

FRANCO JÚNIOR, Hilário - Os três dedos de Adão. Ensaios de mitologia medieval. São Paulo: Edusp, 2010. ISBN 978-85-314-1140-3.

GILSON, Étienne - L'esprit de la philosophie médiévale. Paris: Vrin, 1969. 


\section{COMO CITAR ESTE ARTIGO}

\section{Referência electrónica:}

FRANCO JÚNIOR Hilário - "Similibus simile cognoscitur. O pensamento analógico medieval". Medievalista [Em linha]. N¹4, (Julho - Dezembro 2013). [Consultado dd.mm.aaaa]. Disponível em http://www2.fcsh.unl.pt/iem/medievalista/MEDIEVALISTA14/junior1402.html.

ISSN 1646-740X.

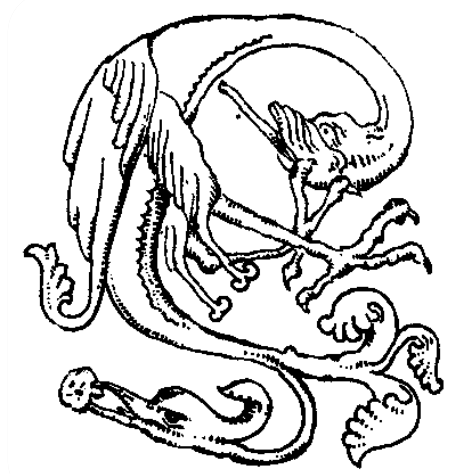

